OPEN ACCESS

Edited by:

Hang Sun,

Kunming Institute of Botany (Chinese Academy of Science), China

Reviewed by:

Sula Vanderplank,

San Diego State University,

United States

Dean Kelch,

California Department of Food and

Agriculture, United States

*Correspondence:

Philip W. Rundel

runde/@biology.ucla.edu

Specialty section

This article was submitted to Biogeography and Macroecology,

a section of the journal

Frontiers in Ecology and Evolution

Received: 15 March 2019 Accepted: 12 September 2019

Published: 27 September 2019

Citation:

Rundel PW (2019) A Neogene

Heritage: Conifer Distributions and Endemism in Mediterranean-Climate Ecosystems. Front. Ecol. Evol. 7:364. doi: 10.3389/fevo.2019.00364

\section{A Neogene Heritage: Conifer Distributions and Endemism in Mediterranean-Climate Ecosystems}

\author{
Philip W. Rundel*
}

Department of Ecology and Evolutionary Biology, Institute of the Environment and Sustainability, University of California, Los Angeles, Los Angeles, CA, United States

The five mediterranean-type climate (MTC) regions of the world, notable for their globally significant levels vascular plant diversity and endemism, fall into two groups. The Cape Region of South Africa and southwestern Australia are ancient and relatively climatically and tectonically stable landscapes with very high species richness relative to their area. This richness reflects a core of paleoendemic lineages as well as Neogene diversification. In contrast, California, the Mediterranean Basin, and central Chile are young climatically and tectonically dynamic landscapes that have developed significant floras in the Neogene. This relative pattern of species richness breaks down when only conifers are considered. Collectively the five MTC regions have a conifer flora of 122 species, almost $20 \%$ of the global total, and are rich in endemic conifers species. This diversity is heavily centered in California with 58 species ( 31 endemic) and the Mediterranean Basin with 40 species (32 endemic). The key to success of conifers in the Northern Hemisphere MTC regions has been the evolution of functional hydraulic traits associated with cold and/or drought tolerance, as exemplified by Neogene diversification in many clades of Pinaceae and Cupressaceae, and by ecophysiological traits that offer competitive advantages over angiosperms on oligotrophic soils. Podocarpaceae and many other Southern Hemisphere conifer lineages never developed equivalent traits and were poorly adapted to surviving increasingly cool and strongly seasonal climate regimes with associated aridity in the late Neogene. Because of extinctions, conifer lineages in the Southern Hemisphere today exhibit a significantly older distribution of divergence ages than their counterparts in the Northern Hemisphere and are home to many isolated relict taxa. This can be seen well in Chile and the Cape Region where there has been little or no Neogene diversification of conifers and a preponderance of relict Gondwanan lineages remain. Only Callitris in southwestern Australia among the Southern Hemisphere MTC floras has been able to evolve successful ecophysiological traits to adapt to aridity in a fire-prone environment and diversify. Traits of cold, drought, and low nutrient tolerance of Northern Hemisphere conifers, most notably in the Pinaceae, have led to their widespread introduction in Southern Hemisphere agroforestry.

Keywords: mediterranean-climate regions, conifers, Pinaceae, Cupressaceae, Podocarpaceae, hydraulic adaptations to drought 


\section{INTRODUCTION}

The five mediterranean-type climate (MTC) regions of the world-California, the Mediterranean Basin, central Chile, the Cape Region of South Africa, and southwestern Australiashare the unusual climate regime of cool wet winters and warm dry summers (Figure 1). All five regions are noted for their remarkable levels of vascular plant species diversity, with each named as a global biodiversity "hotspot." While collectively covering $<3 \%$ of world land area, these regions are home to approximately one-sixth of the global vascular plant flora with a high level of endemism (Cowling et al., 1996). Although the iconic MTC vegetation of all five regions are evergreen scleophyllous shrublands that dominate the landscape, the collective Mediterranean biome includes woodlands and forests often rich in conifers. This diversity has long evoked interest in comparative ecological studies among these five geographically isolated regions with their unique climatic regime. The focus of scientific research has progressed through time from initial generalizations half a century ago describing ecosystem convergence in the five regions to a focus on multiple exceptions to patterns of convergence, and finally to a deeper understanding of processes and ecological relationships that both link and separate individual regions (Rundel, 2011). Today, there is expanding interest in the development of models for the evolution of plant life-history traits in MTC regions to better understand the nature of both past and present selective forces that have shaped diversity and community structure in each of the five regions (Lamont and Downes, 2011; Cowling et al., 2015; Rundel et al., 2016, 2018; Teste et al., 2017). Much of this focus has been on evergreen sclerophyllous shrubs, with less attentions to other life forms.
An interesting feature of the five MTC regions is the differing level of relative plant species richness that exist between the regions across a wide range of spatial scales (Cowling et al., 2015). In this respect, the tectonically older and climatically more stable Cape Region and southwestern Australia stand out (Cowling et al., 2015). The Cape Region is consistently the most diverse of the five regions relative to area at all spatial scales, and arguably among the highest in the world per unit land area (Figure 2). The Cape Region is followed by southwestern Australia in second position for diversity. The older landscapes of these two regions show significant components of both Paleogene and younger Neogene speciation in the origin of their diversity (Cowling et al., 2015; Rundel et al., 2016, 2018). The pattern of vascular plant species diversity for both the western and eastern Mediterranean Basin present lower and intermediate patterns of contemporary plant diversity, followed by California and finally the lowest species richness in central Chile (Cowling et al., 2015; Figure 2). These three regions represent younger landscapes with strong rates of Neogene diversification in flowering plants (Cowling et al., 2015; Rundel et al., 2016).

In view of this pattern of relative species richness between the five MTC regions it is interesting to look at the biogeography and diversity of conifers in these regions. The major conifer lineages present in the world today have evolutionary origins that date back to the Late Triassic, long before the origin of MTCs (Leslie et al., 2018). Although low in numbers of species compared to flowering plants, conifers maintain a disproportionate share of ecological dominance over angiosperms in northern latitudes and high elevation regions of North America and Eurasia with long cold winters (Richardson and Rundel, 1998). Less appreciated, however, is the ability of many conifers to compete successfully against angiosperms in semi-arid seasonal climate regimes in habitats with limited soil nutrient availability.

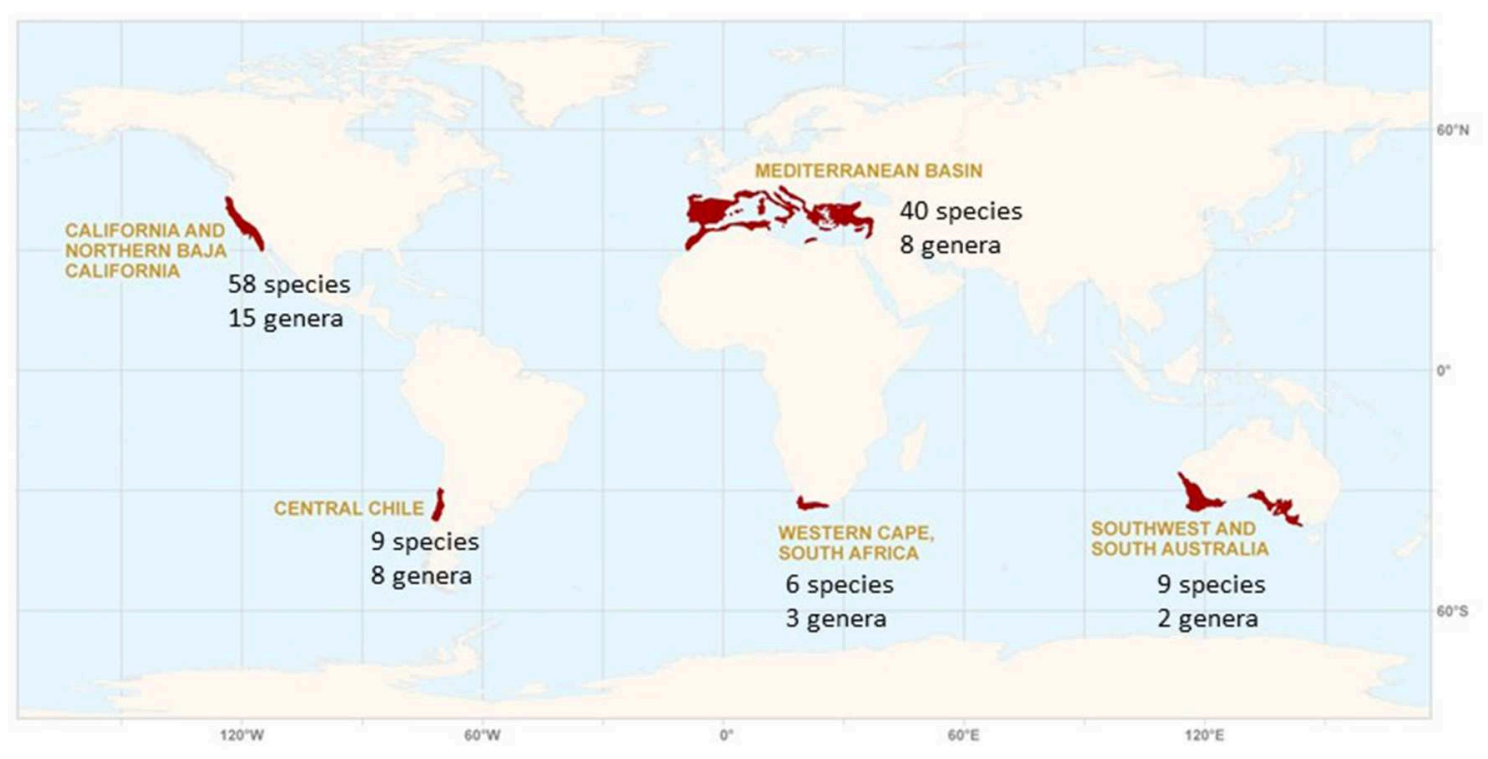

FIGURE 1 | The mediterranean-type climate (MTC) regions of the world and their individual diversity of conifer genera and species. In the text the Chilean region is interpreted broadly to include the wet Valdivian forests of south-central Chile and adjacent areas of Argentina with a winter rainfall regime. 


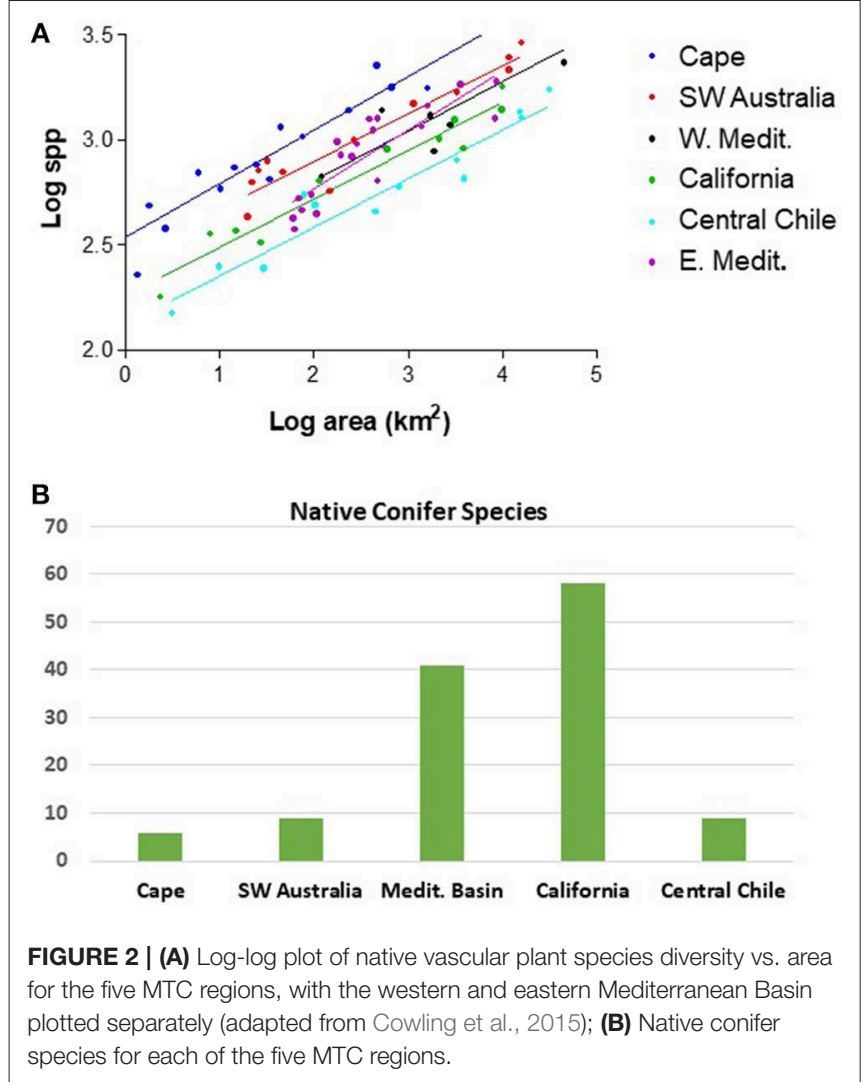

California, one of the young and dynamic MTC landscapes, is a hotspot for conifer diversity with 58 species within the state (Figure 1, Table 1), 9\% of all conifer species in the world, and is home to notable ancient paleoendemic species such as Sequoia sempervirens and Sequoiadendron giganteum (Figure 3). While this total includes a number of wet temperate forest trees whose primary range extends beyond the California MTC region, 31 conifer species are endemic to the region including forest dominants and others competing successfully with angiosperms on oligotrophic or azonal soils. The Mediterranean Basin, another of the relatively young and dynamic landscapes among MTC regions, also possessed a rich conifer flora with 40 conifer species including 32 endemics (Figure 1, Table 1). Many of these are highly restricted in distribution.

In contrast, the otherwise species-rich ancient landscape of the Cape Region is home to only six conifer species with just three of these endemic. Southwestern Australia is home to only two genera and nine species of native conifers, with eight of these endemic. Rather than showing a similar pattern of high conifer diversity as with the two young dynamic landscapes of the Northern Hemisphere, Chile has a native conifer flora with eight genera and nine species, with none of these endemic to the core MTC region of central Chile and all representing ancient Gondwanan lineages.

These biogeographic patterns of conifer distribution and endemism among the five MTC regions differs significantly from that of flowering plant diversity. What factors can explain the relatively low level of conifer diversity in the three
TABLE 1 | Conifer species naturally occurring in mediterranean-type climate (MTC) regions.

\begin{tabular}{|c|c|c|c|c|c|}
\hline Family/Genus & CAL & MED & CHILE & CAPE & SWA \\
\hline \multicolumn{6}{|l|}{ Araucariaceae } \\
\hline Araucaria & & & 1 & & \\
\hline \multicolumn{6}{|l|}{ Cupressaceae } \\
\hline Austrocedrus & & & 1 & & \\
\hline Callitris & & & & & $8(7)$ \\
\hline Callitropsis & 1 & & & & \\
\hline Calocedrus & 1 & & & & \\
\hline Chamaecyparis & 1 & & & & \\
\hline Cupressus & & $3(3)$ & & & \\
\hline Fitzroya & & & 1 & & \\
\hline Hesperocyparis & $12(12)$ & & & & \\
\hline Juniperus & $5(2)$ & $13(12)$ & & & \\
\hline Pilgerodendron & & & 1 & & \\
\hline Sequoia & $1(1)$ & & & & \\
\hline Sequoiadendron & $1(1)$ & & & & \\
\hline Tetraclinis & & $1(1)$ & & & \\
\hline Thuja & 1 & & & & \\
\hline Widdringtonia & & & & $3(2)$ & \\
\hline \multicolumn{6}{|l|}{ Pinaceae } \\
\hline Abies & $7(2)$ & $9(8)$ & & & \\
\hline Cedrus & & $2(2)$ & & & \\
\hline Picea & $3(1)$ & 1 & & & \\
\hline Pinus & $19(10)$ & $10(5)$ & & & \\
\hline Pseudotsuga & $2(1)$ & & & & \\
\hline Tsuga & 2 & & & & \\
\hline \multicolumn{6}{|l|}{ Podocarpaceae } \\
\hline Afrocarpus & & & & 1 & \\
\hline Lepidothamnus & & & 1 & & \\
\hline Podocarpus & & & 2 & $2(1)$ & $1(1)$ \\
\hline Prumnopitys & & & 1 & & \\
\hline Saxegothaea & & & 1 & & \\
\hline \multicolumn{6}{|l|}{ Taxaceae } \\
\hline Taxus & 1 & $1(1)$ & & & \\
\hline \multirow[t]{2}{*}{ Torreya } & $1(1)$ & & & & \\
\hline & $58(31)$ & $40(32)$ & $9(0)$ & $6(3)$ & $9(8)$ \\
\hline
\end{tabular}

Numbers of endemic species shown in parentheses. The California MTC region is expanded to include the winter rainfall desert mountains and the Chilean MTC region is interpreted broadly to include winter rainfall Valdivian forests and adjacent areas of Argentina.

Southern Hemisphere MTC regions? This paper presents an overview of patterns of diversity and endemism for conifer lineages within the five MTC regions and the role of increased Neogene seasonality and associated low temperature extremes and drought in influencing the modern conifer distribution and endemism in contrast to that exhibited by flowering plant species in these regions (Cowling et al., 1996; Rundel et al., 2016). The focus of organization that follows is an is first a description of biogeographic patterns and endemism by family and MTC region, followed by an overview of how climatic changes in the Neogene coupled with traits of ecophysiological adaptation to freezing temperatures and drought have influenced the biogeographic patterns of MTC conifers that are present today. 


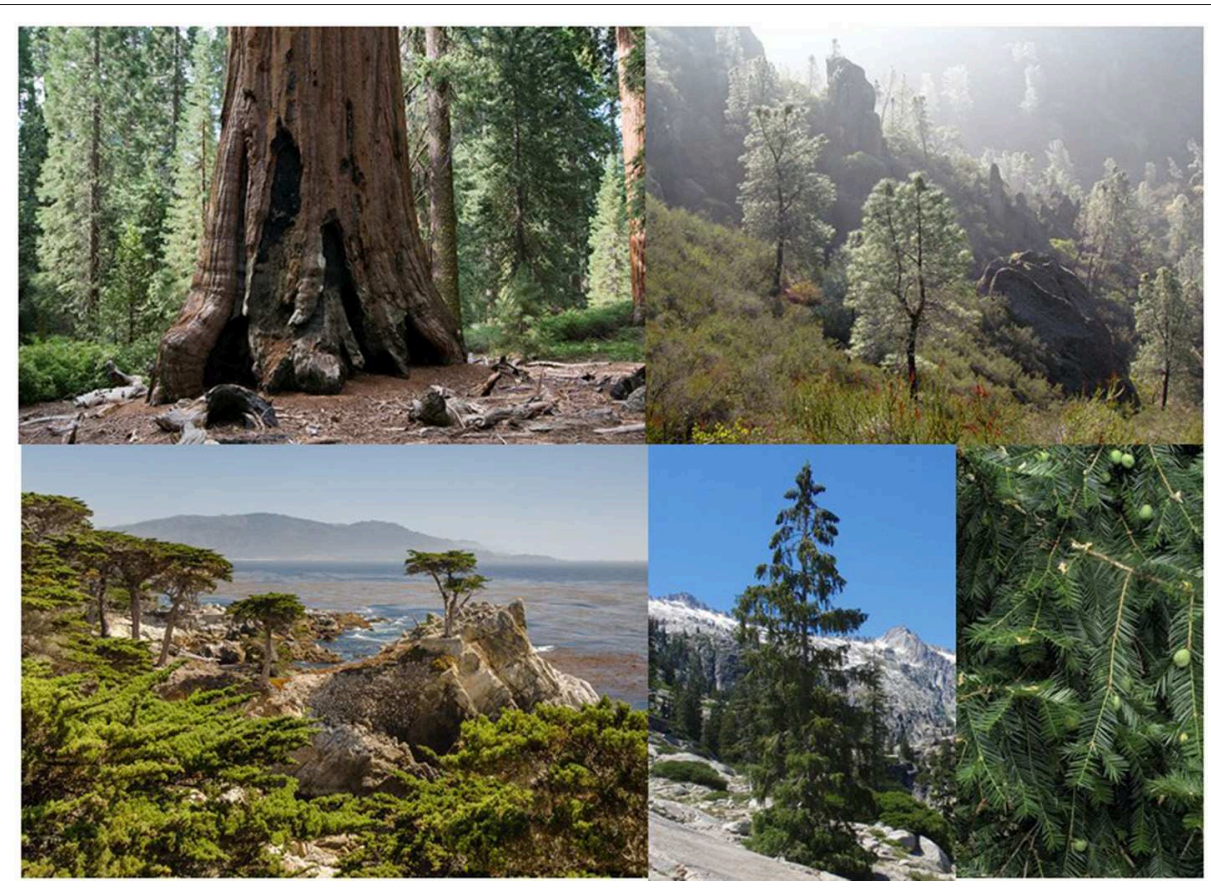

FIGURE 3 | California endemic conifers. Sequoiadendron giganteum, Cupressaceae (photo by Matthew Fong); Pinus sabiniana, Pinaceae (photo by chuck b.); Hesperocyparis macrocarpa, Cupressaceae (photo by Tuxyso); Picea breweriana, Pinaceae (photo by Tom Hilton); Torreya californica, Taxaceae (photo by John Rusk).

\section{ARAUCARIACEAE}

From an origin in the Triassic, the family Araucariaceae expanded and diversified in both hemispheres in the Jurassic and Early Cretaceous (Hill, 1995). Today, however, the family is restricted to the genera Araucaria, Agathis, and Wollemia with a total of about 41 species, all in the Southern Hemisphere. There is abundant fossil evidence for the presence of Agathis in Patagonia from the early Paleocene through the Eocene (Wilf et al., 2014; Escapa et al., 2018), but these wet forests did not survive the seasonality and cooler temperatures of the Oligocene.

Only a single species of the Araucaria survives in a MTC region today, Araucaria araucana from the Valdivian forest region of south-central Chile and adjacent Argentina (Figure 4). The presence of two fossil species related to $A$. araucana in the early Tertiary of southeastern Australia, along with species of Nothofagus in a subgenus now restricted to South America, suggests that there may have been early Tertiary forests in Australia similar to the A. araucana-Nothofagus associations found today near tree line in the Andes (Hill, 1990). Although there is only a limited fossil record for Araucaria in South America, fossils closely related to the Chilean A. araucana have been found in the late Eocene deposits of southern Argentina (Panti et al., 2007).

Araucaria araucana is a massive tree reaching heights up to $50 \mathrm{~m}$ and diameters of more than $2 \mathrm{~m}$, and often referred to as a living fossil. Perhaps most striking about the tree beyond its large size, however, is its unique architecture of branching. The ability of the thick bark to protect living trees from fire and the colonizing ability of seedlings of A. araucana are important traits that have likely aided in its long survival in geologic time. It has a limited range of distribution straddling both sides of the Andes in the northern Valdivian rainforest area. This is a region of high annual precipitation levels of 1,100-4,000 mm, with much of this falling as winter snow. Most of the soils of this area are derived from volcanic flows and cinders. In addition to the primary Andean distribution, there are two small populations of A. araucana in the Cordillera de Nahuelbutia of the Coast Range of Chile on soils derived from granitic and metamorphic parent materials (Burns, 1993; Veblen et al., 1995). During the Last Glacial Maximum A. araucana were mainly confined to valleys (Rabassa and Clapperton, 1990; Ruiz et al., 2007; Marchelli et al., 2010). Additionally, large areas along the Coastal Range and Central Valley of Chile were ice-free during the last glacial maximum and likely served as important glacial refuges for many species (Villagrán, 1995).

\section{CUPRESSACEAE-TRIASSIC ORIGINS OF A HEMISPHERIC SEPARATION}

The Cupressaceae include about 150 species of conifers, with a global range of distribution that occurs over broad ecological habitats on every major continent except Antarctica. Its origins date back to the Triassic when conifers dominated plant cover (Crisp et al., 2019). Five ancient and monotypic or depauperate clades are positioned at the base of the family. These clades were formerly separated as the Taxodiaceae. The ancestors of modern Sequoia, and Sequoiadendron (Figure 3) are thought to have originated at least as early as the Cretaceous (135 Ma), 


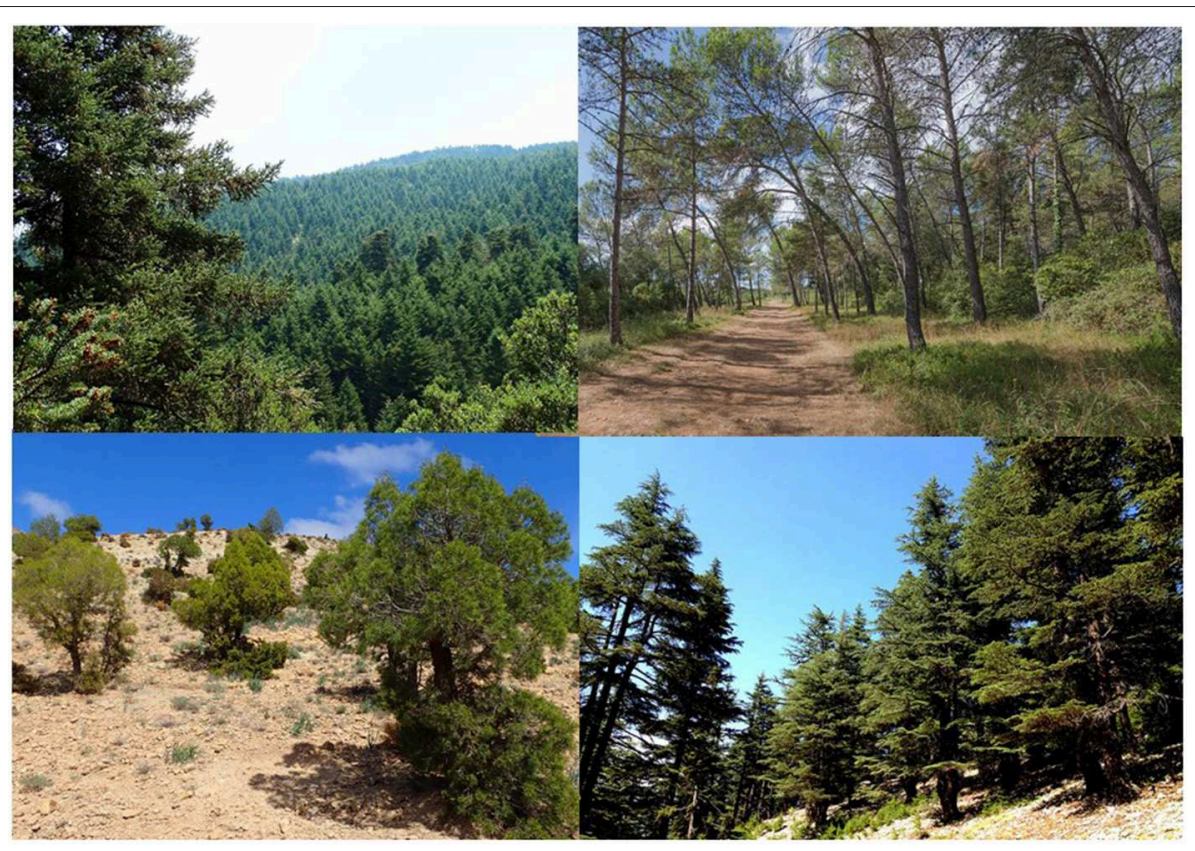

FIGURE 4 | Endemic conifers of the Mediterranean Basin. Abies cephalonica, Pinaceae (photo by Jim Boun); Pinus halepensis, Pinaceae (photo by Christian Ferrer), Tetraclinis articulata, Cupressaceae (photo by Kenraiz); Cedrus libani, Cupressaceae (photo by Zeynel Cebeci).

extending their range from Asia at the beginning of the Cenozoic era (65 Ma) to the Arctic region and into North America (Sawyer et al., 2000). Climate change during the Miocene and Pliocene (40-10 Ma) led to the extinction of these species in Europe and Asia. The present restricted distribution of the redwoods is thought to have been caused by a combination of increased climate seasonality in the Miocene combined with mountain orogenies and late Pliocene-Pleistocene glaciations over the past $2 \mathrm{Ma}$. The fossil analog of modern S. sempervirens first appears in Paleocene to middle Eocene floras from Wyoming, Montana, and Colorado, and late Eocene floras of Nevada and Idaho (Axelrod, 1976, 1986). Modern communities with S. sempervirens were well-established along the coast of California and southern Oregon in the Pliocene, extending southward into Southern California during cooler and wetter periods of the Pleistocene (Sawyer et al., 2000). Miocene floras with Sequoiadendron occur in Nevada and Idaho and formed communities much like those in its habitat today in the Pliocene of western Nevada. The discontinuous distribution of Sequoiadendron groves today is due to a variety of effects of Pleistocene glaciations and Holocene climate change (Rundel, 1972).

Crown Cupressaceae originated in the Jurassic and diverged into two major clades, the Cupressoideae and Callitroideae (Gadek et al., 2000; Leslie et al., 2018). In the Cretaceous following the breakup of Pangea and separation of Laurasia and there was a radiation of the Cupressoideae on the new Laurasian continent in the Northern Hemisphere and the Callitroideae on Gondwana in the Southern Hemisphere (Mao et al., 2012; Leslie et al., 2018). Like the ancient mesic forest ancestors, many clades within the Cupressoideae and Callitroideae maintained a strong habitat relationship to cool and wet temperate forests. However, at least three clades evolved drought-resistant ecophysiological strategies for survival allowing a broader ecological amplitude of habitat. Several genera that were able to adapt well-experienced bursts of diversification in the Miocene and continuing into the Quaternary. This pattern can be seen in Hesperocyparis in California and Juniperus in Eurasia (Mao et al., 2010) in the Northern Hemisphere and Callitris in Australia (Larter et al., 2017; Crisp et al., 2019). Key to this survival was the evolution of drought resistant xylem coupled to increased carbon investment in xylem tissue, reduced xylem transport efficiency, and at the leaf level, reduced photosynthetic capacity (Pittermann et al., 2012). Despite extinctions, Callitris was able survive and radiate into dry, fire-prone biomes that expanded in the Neogene, with serotiny evolving as a key adaptation to fire (Crisp et al., 2019). The ecological success of these species in competition with angiosperms can be best seen in semi-arid seasonal climate regimes on skeletal soils with low nutrient availability.

\section{Cupressoideae in California}

The greater California MTC region is home to a rich assemblage of taxa in the Cupressoideae, which includes outliers of mesic lineages such as Thuja and Chamaecyparis with widespread distribution in the early Tertiary as well as more derived drought adapted lineages (Donoghue and Smith, 2004; Li and Xiang, 2005). The genus Hesperocyparis includes 12 species occurring in California and northwestern Baja California (Terry et al., 2016), all once included in a broad concept of Cupressus (Wolf, 1948). Four additional species occur outside of California, two in Arizona and two in Mexico and Central America. Rather than having a close relationship with Eurasian species of Cupressus, molecular studies have shown that Hesperocyparis is most 
closely related to the northwestern North American Callitropsis nootkatensis and the Southeast Asian Xanthocyparis vietnamensis (Adams et al., 2009; Terry et al., 2016). Diversification has been active in Hesperocyparis and all species are apparently no more than late Miocene (6 Ma) in age with net diversification rates in the group are among the highest reported to date for gymnosperms (Terry et al., 2016). All species in the genus are highly restricted in their range of distribution and typically occur in small populations on azonal soils such as serpentines, ultramafics, and podzols (H. macnabiana, H. pygmaea, H. bakeri, and $H$. forbesii) or in areas characterized by a high frequency of summer fog often coupled with azonal soils [H. macrocarpa (Figure 3), H. goveniana, H. abramsiana, and H. guadelupensis]. Although most species occur in the Coast Ranges of California, $H$. nevadensis and $H$. arizonica occur in dry interior climate regions and $H$. montana reaches to cool and dry elevations over 3,000 m in the Sierra San Pedro Martir of Baja California (Rehfeldt, 1997). Many if not most species of Hesperocyparis are considered rare and endangered because of their small population sizes (Terry et al., 2016).

The genus Juniperus forms a major component of arid and semiarid shrublands across the northern hemisphere from Europe and central Asia to North America with a total of 67 species representing relatively young clades of diversification in both the Mediterranean Basin and western United States as well as in Asia (Adams, 2008). Juniperus is thought to have originated in Eurasia and formed a major element of the warm temperate semiarid south vegetation of the Eocene and Oligocene (Mao et al., 2010). It is one of many genera of Madro-Tethyan distribution which dispersed between the Mediterranean Basin and western North America at that time, and fossil records suggest that the section Sabina was well-established in both Europe and North America by the late Oligocene (Axelrod, 1975). Four of the five California species of Juniperus are derived from this clade of semiarid temperate species. Two of these, $J$. californica (California juniper) and J. grandis (Sierra juniper) are largely restricted to the California MTC region with its associated winter rainfall deserts, while J. occidentalis (western juniper) and J. osteosperma (Utah juniper) have a range extending eastward into the Great Basin. There was a second dispersal of cold-adapted European junipers to North America in the Miocene, but none of the derived species occurs in California. The fifth California juniper, J. communis (mountain juniper), is a circumboreal species with a relatively recent arrival in North America (Mao et al., 2010).

Calocedrus (incense cedars) provides an example of genera with a disjunct eastern Asia to western North America distribution today. The North American species, Calocedrus decurrens, occurs in relatively xeric montane forests from the Cascade Range of Oregon through the Sierra Nevada into the Sierra San Pedro Martir of Baja California. These trees can reach to almost $50 \mathrm{~m}$ in height with diameters of more than $3 \mathrm{~m}$. There are numerous Tertiary fossil records of Calocedrus in eastern and southeastern Europe, as well as Oligocene and Miocene records from the Pacific Northwest of Alaska and Oregon and the Miocene of China and Japan (see Chen et al., 2009). Normally four species are recognized with a clade of three species three from eastern Asia and Indochina and another from western North America. These clades have an estimated divergence time from their most recent common ancestor of about $25 \mathrm{Ma}$ (Chen et al., 2009).

Three genera of large forest trees in California are outliers from a primary range occurring in wet temperate forest habitats to the north-Thuja, Chamaecyparis, and Callitropsis. Thuja plicata (western red cedar) is a large forest tree with a range that covers coastal wet temperate forests from northern California to Alaska, and in areas of the Rocky Mountains in western Montana. Thuja includes five species in total today with three in Japan, Korea and China, and one in the northeastern United States and adjacent Canada, but the genus had a much broader range in the Cretaceous and Paleogene (Li and Xiang, 2005).

A more restricted pattern of Pacific Northwest distribution is present in Chamaecyparis lawsoniana (Port Orford cedar), a species with a narrow range occurring in the wet temperate forests along $<300 \mathrm{~km}$ of coastal slopes in northwestern California and southern Oregon. These likewise are huge trees with record heights up to $65 \mathrm{~m}$ and diameters up to $6 \mathrm{~m}$. There are five species in total in the genus Chamaecyparis, with three in Taiwan, China, and Japan, and one on the southeast and east coast of the United States.

A related species is C. nootkatensis (Alaska yellow cedar) considered now as a monotypic genus with a range of distribution from the Klamath Mountains of northwestern California to Prince Williams Sound in Alaska. Individual trees can reach as tall as $50 \mathrm{~m}$ in height and commonly have diameters of $2 \mathrm{~m}$ or more, with a record tree of $3.7 \mathrm{~m}$ diameter. It was once placed in the genus Chamaecyparis and is closely related to X. vietnamensis from northern Vietnam and considered by some to be congeneric (Terry et al., 2016).

\section{Cupressoideae in the Mediterranean Basin}

Like California, the Mediterranean Basin is home to both relict paleoendemic and prominent neoendemic members of the Cupressoideae. A classic example of a relict paleoendemic is the genus Tetraclinis, known from a single extant species, T. articulata (arar). This is a small tree that occurs in a restricted range centered in the Atlas Mountains of Morocco, Algeria, and Tunisia, with small outlying populations on Malta, and in southeast Spain (Figure 4). It grows to heights of 6$15 \mathrm{~m}$ or occasionally $20 \mathrm{~m}$ in relatively low elevation areas with a hot, dry subtropical Mediterranean climate (Médail et al., 2009). The narrow modern range of $T$. articulata masks a much larger past range of distribution. There is good fossil evidence that Tetraclinis occurred widely across Europe in the Miocene and Pliocene, with a range reaching to the Canary Islands. More surprising is a fossil record of Tetraclinis seed cones, seeds, and foliage across the western United States in the Oligocene and Miocene (Kvaček et al., 2000). It appears to fit the biogeographic pattern of Madro-Tethyan species distributions (Axelrod, 1975) as there is no evidence of its occurrence in the fossil record in Asia. 
The genus Cupressus includes the widespread C. sempervirens from the eastern Mediterranean Basin (Mediterranean or Italian cypress) and two closely related rare endemics-C. atlantica from the Atlas Mountains of Morocco and C. dupreziana (Saharan cypress) from the Tamrit Plateau of southeastern Algeria. These species became differentiated in the Neogene is response to cycles of aridity in the Mediterranean Basin (Sekiewicz et al., 2018). Although there is a limited Tertiary fossil record of Cupressus, fossil wood and cones of Miocene/Pliocene age have been found over much of Western Europe and east to the Caucasus (Bagnoli et al., 2009). Scattered Quaternary fossil occurrences of $C$. sempervirens in Italy, Crete, Cyprus, and the Near East support the suggestion that these were past areas of natural occurrence.

As described above, the genus Juniperus forms a major component of arid and semiarid shrublands across the northern hemisphere from Europe and central Asia to North America (Adams, 2008). There are at least 13 species of Juniperus in the Mediterranean Basin, including members of all three sections of the genus (Adams, 2008). The sections Juniperus and Caryocedrus first appear in the fossil record in the middle Miocene of Europe. The putative ancestral section Sabina underwent a burst of speciation with the development of the sclerophyllous semiarid Tethyan vegetation in the Eocene, and then slowed in diversification with the more stable climate-vegetation structure of the Oligocene and Early Miocene. Diversification again accelerated from the Late Miocene to late Pliocene as progressive cooling of the earth from generated increasing areas of semiarid habitats favored by junipers (Mao et al., 2010). There are four Mediterranean Basin junipers in this group. Juniperus excelsa (Greek juniper) from the eastern Mediterranean is an important species that often forms the treeline at high elevations. The section also includes J. foetidissima (fetid juniper) from southeastern Europe and the eastern Mediterranean, J. polycarpos (Persian juniper) from Iran to Pakistan, and $J$. thurifera (Spanish juniper) with a disjunct pattern of distribution of scattered populations in Morocco, northern Algeria, Spain, Southern France, and Corsica. This unusual pattern of distribution that likely resulted from cycles of climate change over the Quaternary (Terrab et al., 2008). During the Late Pleistocene up to 14,000$12,000 \mathrm{ka}$, the species is thought to have been more widely distributed across the western Mediterranean Basin in cold-adapted open woodlands with steppe-like undercover (Jalut et al., 1992; Quézel et al., 1999).

The sections Juniperus and Caryocedrus first appear in the fossil record in the middle Miocene of Europe but are unknown in either North America or Asia. Juniperus drupacea, the largest juniper reaching heights of up to $40 \mathrm{~m}$ more and diameters of $1-2 \mathrm{~m}$, is the only member of the section Calyocedrus. It is distributed in the eastern Mediterranean Basin from southern Greece and Turkey to Syria and Lebanon where it grows on rocky hillsides. There are eight species of juniper in the Mediterranean Basin that are part of the section Juniperus. These include J. phoenicea (Phoenician juniper) from across the entire Mediterranean Basin, J. oxycedrus (prickly juniper) occurring across the Mediterranean Basin, J. macrocarpa (large-fruited juniper) from the northern Mediterranean Basin, J. deltoides (eastern prickly juniper) from the eastern Mediterranean Basin, $J$. navicularis (Portuguese prickly juniper) from Portugal, J. cedrus (Canary Island juniper) from Madiera and the Canary islands, $J$. brevifolia (Azores juniper) from the Azores, and the circumboreal J. communis (mountain juniper).

\section{Callitroideae in Chile}

The three taxa of Cupressaceae subfamily Callitroideae in ChileAustrocedrus chilensis, Fitzroya cupressoides, and Pilgerodendron uviferum-are relict monotypic genera that are part of a Gondwanan clade that originated in the late Cretaceous or early Paleocene (Leslie et al., 2018). All have their primary range of distribution in the wet winter rainfall forests to the south of the core MTC region. Austrocedrus chilensis (ciprés de la cordillera) is distributed in two discontinuous corridors on either side of the Andean Cordillera, in central and southern Chile and Argentina (Pastorino et al., 2004). The Chilean populations are more northerly than those of Argentina, reaching almost to the latitude of Santiago and include scattered relict stands in the coastal mountains as at Nahuelbutia. On the Argentine side of the Andes Austrocedrus is found in small isolated groups of trees, and as conspicuous forests stands further south (Veblen et al., 1995; Pastorino et al., 2004). It occurs over precipitation levels from about $2,500 \mathrm{~mm}$ or more at higher elevations of the Andes where it grows in mixed dominance with evergreen angiosperm trees to precipitation levels as low as $600 \mathrm{~mm}$ at its eastern margin at the forest-steppe ecotone in Argentina where it forms open monospecific stands. Over all of its range there is a strong MTC regime of seasonal rainfall. Austrocedrus is notable for its variable growth form, which ranges from multistemmed shrubs at the drier xeric conditions to tall forest trees up to more than $35 \mathrm{~m}$ in height in its wetter range. The shade intolerant trees are long-lived, with ages up to 1,000 years or more (Veblen et al., 1995).

Although Austrocedrus today represents a monotypic conifer genus, fossils of Austrocedrus are known from the Oligocene and early Miocene of Tasmania (Paull and Hill, 2008). As with other Chilean conifers, most of the current distribution range of Austrocedrus was covered by ice at the time of glacial maximum (Pastorino and Gallo, 2002). Because Austrocedrus is highly sensitive to fire and must reproduce from seed, it is range has likely increased and decreased regularly through the Holocene in response to increased and decreased fire frequency.

Fitzroya cupressoides (alerce) forms a monotypic genus know today only from scattered populations over a limited geographic range in the Coastal Range and central valley of south-central Chile, and on the western and eastern slopes of Andes in Chile and Argentina in areas of high precipitation (Figure 5; Allnutt et al., 1999; Premoli et al., 2000). Populations in the Chilean central valley were extensively logged and cleared for agriculture in the mid-nineteenth century by European colonists. This previous extent of Fitzroya forests can be seen today in large numbers of cut and burnt stumps that remain in this area (Armesto et al., 1995). With its large size extending to $50 \mathrm{~m}$ in height and $5 \mathrm{~m}$ in diameter, as well as its reddish-brown bark, 


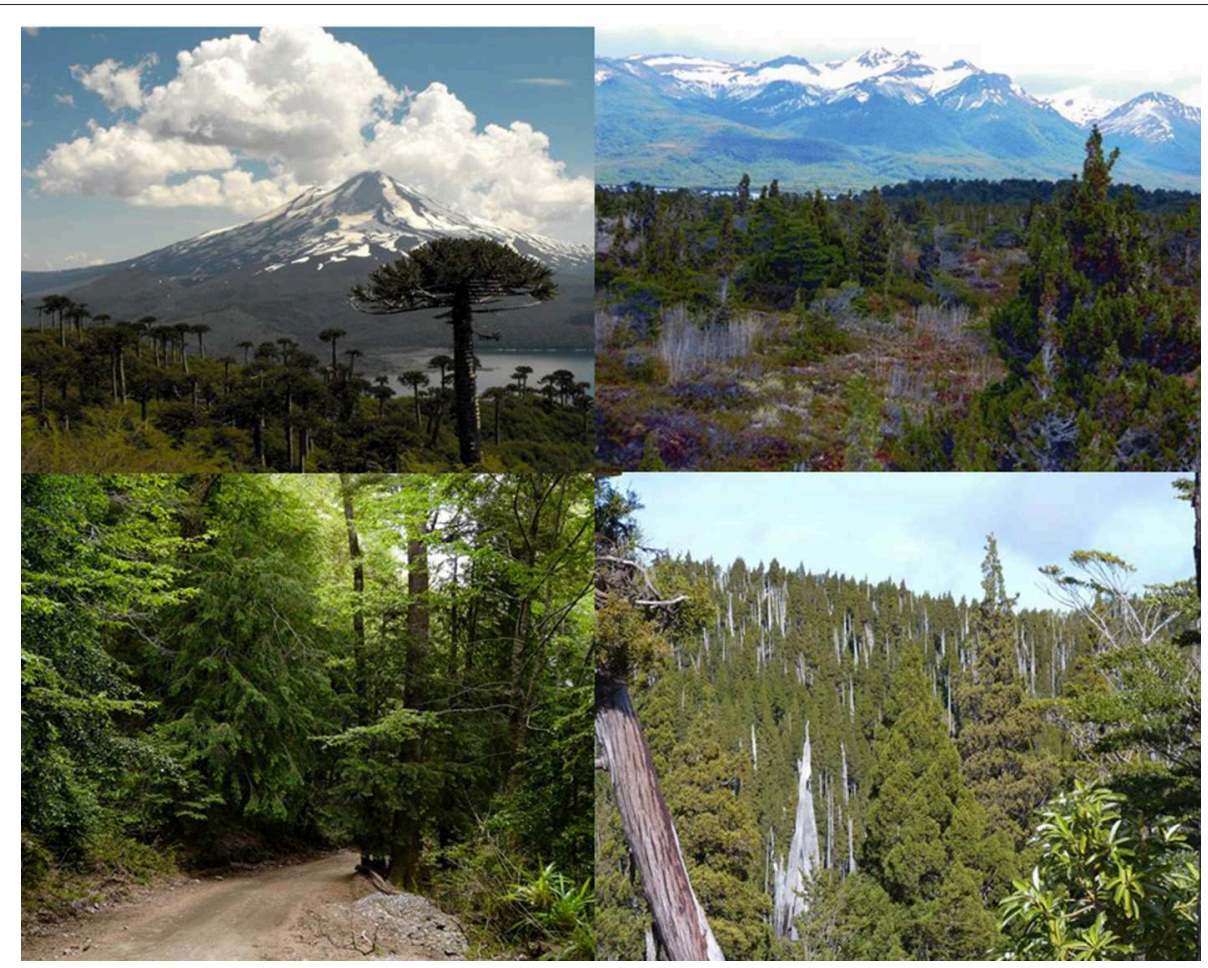

FIGURE 5 | Endemic Chilean conifers. Araucaria araucana, Araucariaceae (photo by lautaroj); Pilgerodendron uviferum, Cupressaceae (photo by Rodolfo Iturraspe); Podocarpus nubigenus, Podocarpaceae (photo by Fedwerner); Fitzroya cupressoides, Cupressaceae (photo by Mono Andes).

Fitzroya superficially resembles the redwoods. Beyond its very large size, one of the notable features of Fitzroya is the age that it can attain. A large tree in Chile has been cross-dated to 3,622 years, with only Pinus longaeva known to reach greater ages (Lara and Villalba, 1993). Reproduction in Fitzroya occurs almost entirely from seeds, which germinate and grow best in large forest gaps (Veblen et al., 1995).

Fitzroya represents a relict Gondwanan lineage, with the genus having a range of occurrence that extended to Tasmania in the Oligocene (35 Ma) (Hill and Whang, 1996; Paull and Hill, 2010). There are also controversial fossil records of $F$. cupressoides from upper Cretaceous deposits in Argentina. Little is known, however, about its late Tertiary distribution in South America. Glacial conditions had a profound impact on Fitzroya, reducing its range to small coastal refugia in south-central Chile. Following the retreat of the glaciers from their maximum around $18 \mathrm{ka}$, populations of Fitzroya and other Valdivian forest tree species expanded from glacial refugia in the Coastal Range and possibly from ice free areas of the central valley and the eastern slopes of the Andes (Allnutt et al., 1999; Premoli et al., 2000, 2003).

Pilgerodendron uviferum (ciprés de las Guaitecas) has a very broad geographic range extending over $1,600 \mathrm{~km}$ in southern Chile and adjacent parts of Argentina to south of Tierra del Fuego, making it the southernmost conifer in the world (Figure 5). Although placed in a monotypic genus, the close relationship of Pilgerodendron to species of Libocedrus in New Zealand suggests that it could be easily accommodated in that genus (Gadek et al., 2000). The genus is relatively young, having diverged in the Miocene about $15 \mathrm{Ma}$ (Larter et al., 2017) or earlier at about $25 \mathrm{Ma}$ in the late Oligocene (Mao et al., 2012; Leslie et al., 2018). Despite this wide latitudinal range, populations of Pilgerodendron tend to be small and locally restricted to wet and poorly drained azonal sites (Premoli et al., 2002). These are typically habitats with cool temperature conditions and high levels of annual precipitation of 2,000$4,000 \mathrm{~mm}$ or more annually and are often associated with Sphagnum bogs (Allnutt et al., 2003).

\section{Callitroideae in the Cape Region}

The presence of Cupressaceae in the Cape Region of South Africa is limited to three species of Widdringtonia, all shrubby trees that occasionally reach to heights of $10-20 \mathrm{~m}$ or more (Midgley et al., 1995; Pauw and Linder, 1997). Two of these are species highly restricted to local areas of the Cape Fold Mountains. The clade has an origin that dates back about $50 \mathrm{Ma}$ to the Eocene (Larter et al., 2017), but existing species all have a Neogene origin (Crisp et al., 2019). Although confined to southern Africa today, it has been suggested that Widdringtonia had a broad distribution over North America, Europe, and Greenland during the midCretaceous and persistence in Europe well into the Tertiary (McIver, 2001). Cupressaceae fossils from the Eocene of South Australia also appear to represent Widdringtonia (Pledge, 2002).

The existing species Widdingtonia wallichii (Clanwilliam cedar, Figure 6) is known from only a small area of the Cederberg Mountains north of Cape Town. This species is largely confined to canyon locations and its numbers are so low 
that natural population recruitment is highly limited. Because it is an obligate reseeding species that does not resprout after fires, much like California cypress species, W. wallichii can be eliminated by fires that occur at intervals which are shorter than the maturation rate for this species (Manders, 1987). Widdringtonia schwartzii (Willowmore cedar), also an obligately reseeding species after fire, is locally distributed in the Baviaanskloof and Kouga Mountains of the Eastern Cape where it is present in scattered populations at 70$1,220 \mathrm{~m}$ elevation in rocky ravines of low rainfall areas. The third species, $W$. nodiflora (mountain cypress) has a widespread geographic range that extends from Malawi to the Western Cape Region where it occurs in ericaceous heath habitats. Unlike other species in the genus, $W$. nodiflora has the ability to resprout after fire from its basal lignotuber (Midgley et al., 1995).

\section{Callitroideae in Southwestern Australia}

The genus Callitris (cypress pines) includes about 21 extant species with a wide range of distribution including both western and eastern Australia, and with two species reaching north to New Caledonia. Fossils of Callitris appear in several areas of Australia as early as the Oligocene and this fossil record has aided in establishing a detailed and dated phylogeny for the genus (Crisp et al., 2019). There are older reports suggesting the presence of Callitris in North America and Europe, but these remain equivocal (Brown, 1935; Greguss, 1970).

There are eight Callitris species in southwestern Australia, including three shrubby taxa formerly segregated as the genus Actinostrobus, with seven of these endemic to the MTC region (Piggin and Bruhl, 2010). Most Callitris species, with those once placed in Actinostrobus as exceptions, occur as local stand dominants in azonal habitats such as rock outcrops, hill slope breakaways, margins of swamps, and around salt lakes. There is molecular evidence for at least two transAustralian migrations within the genus. Callitris drummondii (Drummond's Cypress) in southwestern Australia along with the three former Actinostrobus species (C. acuminatus, C. arenarius, and C. pyramidalis) form part of a basal group, while $C$. preisii (Rottnest Island pine, Figure 6) in southwestern Australia is most closely related to two species in eastern Australia (Pye et al., 1998).

The radiation of Callitris from mesophytic ancestors was driven by the aridification of the Australian continent during the last $30 \mathrm{Ma}$ (Crisp et al., 2019). The contraction of Eocene rainforests and expansion of seasonally dry, fire-dominated sclerophyll communities across Australia led to a pulse of extinction of Callitris species (Hill, 2004; Hill and Brodribb, 2006; Crisp and Cook, 2013). Unlike most Podocarpaceae and Araucariaceae, Callitris was able to survive and undergo Neogene speciation in the sandplains and azonal edaphic habitats of southwestern Australia through the evolution of key adaptive traits of drought resistance (Hill and Brodribb, 2006; Crisp et al., 2019). Over this period mechanisms for highly drought-resistant xylem morphologies resistant to the formation of embolisms have evolved multiple times independently in different lineages within the group. Species from more xeric areas have evolved smaller tracheids with both wood traits and embolism-resistance totally disconnected from overall xylem conductivity. This suggests a lack of tradeoffs between construction costs and safety, on the one hand, and efficiency on the other. Callitris tuberculata from southwestern Australia has been declared the most cavitation-resistant tree species in the world based on mean xylem pressure leading to $50 \%$ loss of hydraulic function (Larter et al., 2015, 2017). Serotiny has evolved as another adaptive trait in sandhill communities subject to frequent intense crown fires (Crisp et al., 2019).

\section{PINACEAE}

The Pinaceae, the largest family of conifers with 11 genera and 230-250 species, depending on taxonomic views, is almost entirely a Northern Hemisphere lineage. The family is primarily temperate in distribution, with centers of diversity in the mountains of southwest China, Japan, Mexico, and California. Only a single species of Pinaceae in Malesia extends slightly into the Southern Hemisphere. The MTC regions of California and the Mediterranean Basin provide a wealth of habitats rich in diversity of Pinaceae with classic examples of both relict paleo-endemics and Neogene/Quaternary diversification. In both Europe and North America pines can in many respects be considered as the eucalypts of the northern hemisphere in that they represent a fire-adapted lineage that dominates forest ecosystems with seasonal climates (He et al., 2012). Also, like the eucalypts, pines predate the development of MTC regimes and are widely distributed across much of and North America, Europe, and Asia (Richardson and Rundel, 1998).

The origin of Pinus dates to the Cretaceous but its radiation is a Cenozoic phenomenon (Millar, 1993). Sometime in the Cretaceous the subgenus Pinus (yellow pines) separated from the subgenus Strobus (white pines). Many members of the former group have distributions today associated with fire-prone ecosystems while latter clade radiated into climatically stressful habitats such as semi-arid or subalpine environments (Keeley and Zedler, 1998; Schwilk and Ackerly, 2001).

Faced with intense competition from the rapidly radiating angiosperms, pines, and other gymnosperms were at a decided disadvantage in warm and mesic conditions (Bond, 1989). Consequently, climates through much of the Eocene severely limited conifer distribution to high latitudes and/or high elevations in both Europe and North America (Millar, 1993). The cooling and drying conditions of the Oligocene provided an epoch of range expansion of conifers in North America, with the early to middle Miocene the time of extensive evolutionary radiation (Millar, 1993; Willyard et al., 2006). Climatic conditions of the Pleistocene further stimulated diversification (Eckert and Hall, 2006).

\section{Pinaceae in California}

There are 19 species of Pinus naturally occurring within California. These include several species with wide ranging distribution across the western United States, but many are 


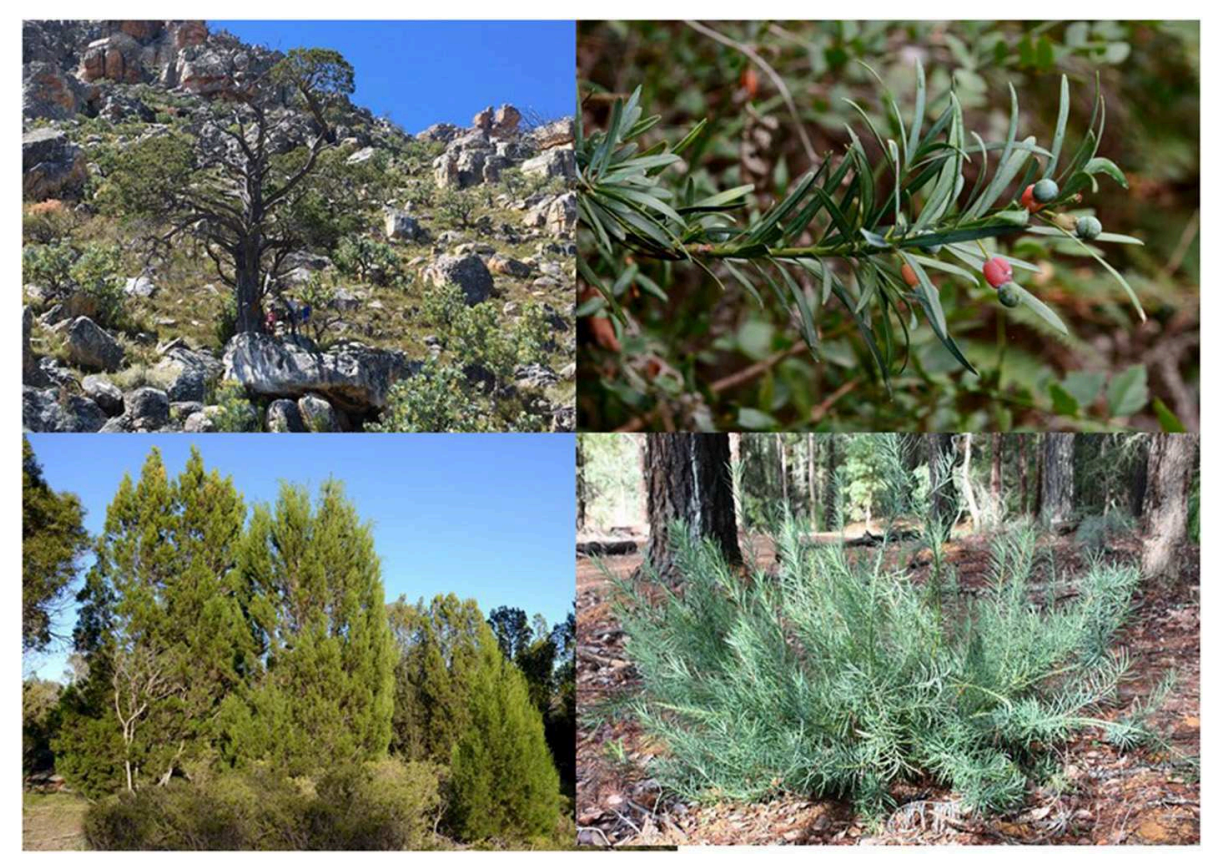

FIGURE 6 | Endemic conifers from the Cape Region of South Africa: Widdringtonia wallichii, Cupressaceae (photo by Linda Marie Botes); Podocarpus elongatus, Podocarpaceae (photo by galanhsnu), and Southwestern Australia: Callitris preissii, Cupressaceae (photo by Botanic Gardens and Parks Authority), Podocarpus drouyanianus, Podocarpaceae (photo by Hesperian).

relatively restricted endemics. Both the yellow pines (subgenus Pinus) and the white pines (subgenus Strobus) are wellrepresented. The yellow pines include a diverse group of species in the subsection Ponderosae with two clusters of closely related species. One group of montane taxa includes $P$. ponderosa (ponderosa pine), P. jeffreyi (Jeffrey pine), and P. washoensis (Washoe pine). The first of these is widely distributed across the western United States while the latter two are endemic to the California MTC region. The other group is formed by three endemic species of coastal and foothill pine-P. sabiniana (foothill pine, Figure 3), $P$. coulteri (Coulter pine), and $P$. torreyana (Torrey pine). The subsection Attenuata contains three more endemic species also restricted to coast and foothill habitats. These are $P$. attenuata (knobcone pine), $P$. muricata (Bishop pine), and $P$. radiata (Monterey pine). The latter two species are notable for a highly disjunct pattern occurrence along the California and Baja California coast (Axelrod, 1980; Millar et al., 1988; Millar, 1999; Wu et al., 1999).

The final member of the subgenus Pinus is P. contorta in the subsection Contortae with a very wide distribution across the western United States that can be separated into four distinctive subspecies. Two of the subspecies are endemic to California, including $P$. contorta subsp. murrayana (lodgepole pine) forming upper montane forests in the Sierra Nevada and Cascade ranges and the highly localized $P$. contorta subsp. bolanderi (Bolander pine) restricted to small areas of highly podzolized beach terraces along the northern California coast. A third taxa, P. contorta subsp. contorta (beach pine) occurs along the coast of northern California but extends its range north into British Columbia.
There are nine species of white pines in California, a group that includes the pinyons. The section Parryae subsection Cembroides is represented by three species of pinyon pines occurring in the state. Pinus monophylla (singleleaf pinyon) and $P$. edulis (Colorado pinyon) both occur widely across the Great Basin although the latter only barely enters California, and $P$. quadrifolia (four-needle pinyon) is endemic to southern California and northwestern Baja California. The latter species shows closest relationships to pinyon taxa in summer rainfall areas, suggesting that vicariance may have been more important than long distance dispersal in the evolution of taxa which have relatively recently evolved tolerance to summer drought (Malusa, 1992; Gernandt et al., 2003).

Four white pine species are subalpine to treeline specialists that represent two distinct lineages among the subgenus Strobus section Parryae. The first group with Mexican ancestry includes $P$. longaeva (Great Basin bristlecone pine) and the endemic Pinus balfouriana (foxtail pine) which are members of the subsection Balfourianae, together with Pinus aristata (Colorado bristlecone pine) from the southern Rocky Mountains (Eckert, 2008). Pinus longaeva is famous as the oldest living conifer in the world, with a tree from eastern Nevada dated by tree rings to 4,844 years. This species has a Great Basin range of distribution and enters California in the White Mountains where it has a restricted distribution on shallow dolomite soils and extends to nearly 3,700 m elevation. The second group in the subsection Cembrae includes P. albicaulis (whitebark pine) and $P$. flexilis (limber pine), a group of Eurasian ancestry, with 
both species widely distributed across the western United States and Canada.

The final two white pines are members of the section Strobus, subsection Strobi. Pinus lambertiana (sugar pine) is an important montane species in the Sierra Nevada and attains sizes larger than that of any other pine in the world. The range of this species extends into southern Oregon only a small distance outside of the California MTC region. It is replaced at higher elevations in upper montane and subalpine forests by $P$. monticola (western white pine).

The genus Abies, the firs, has a broad distribution in temperate forests across the northern hemisphere in North and Central America, Europe and Asia, and includes about 40 species. The genus is characterized by several very widespread species but also contains highly localized species occurrences with one example of a paleoendemic and others as neoendemics. Seven of the nine species in United States and Canada are present within the California MTC region. These represent a diverse ancestry with five separate subgenera of Abies represented (Xiang et al., 2004, 2009). However, five of these are species that have the major portion of their distributions in wet temperate forests of the Pacific Northwest and/or Rocky Mountains, while the other two are endemic to the California MTC region.

One pair of related species is formed by Abies concolor (white fir), the dominant fir of mixed conifer forests in the lower montane zone of the Sierra San Pedro Martir of Baja California north along the Sierra Nevada and into southern Oregon, and Abies grandis (grand fir) which has a broad range from lower elevations of the Coast Range of northern California north into British Columbia and east into the northern Rocky Mountains. The two species hybridize where their ranges overlap in southern Oregon. A distinct variety of white fir is present in the Rocky Mountains and has relict populations in high mountain areas of the eastern Mojave Desert in California.

One of the most interesting distributions of Abies in California can be seen with A. magnifica (red fir), an upper montane endemic species. There are two distinct taxa, with the var. shastensis present in the southern Sierra and to the north in the Klamath Mountains, while the var. magnifica is present in the central and northern Sierra Nevada (Fites-Kaufman et al., 2007). Closely related to A. magnifica is A. procera (noble fir) which replaces it to the north. The latter occurs in wet forest habitats in the Cascade Range of Oregon and Washington just outside of the California MTC region but in a climate regime strongly dominated by winter precipitation with dry summers. Two additional wet forest fir species, each in a different subgenus, have a range centered in the Pacific Northwest but have relict populations that survive in the Klamath Mountains of northern California. Abies amabilis (silver fir) occurs at moderate to high elevations in the Cascade Range and north into British Columbia and is known from two populations in California. Abies lasiocarpa (subalpine fir) has a broad range from the Cascade Range north into Canada and across the northern Rocky Mountains at high elevations but occurs in six small and highly fragmented populations in California.
Abies bracteata (Santa Lucia fir), the seventh species, is a unique paleoendemic and the sole member of the subgenus Bracteata (Ledig et al., 2006). This species is restricted to a highly fragmented group of small populations in the Santa Lucia Mountains of central coast California and may be a relict of broadleaved evergreen sclerophyll forests of the Miocene. Axelrod (1976) compared A. bracteata to a fossil Abies from the Miocene of Nevada and suggests that it may have had a wider distribution in the Coast Ranges during the moister phases of the Quaternary.

The genus Picea, or spruces, includes about 35 species of trees distributed in temperate forests throughout the Northern Hemisphere. The oldest fossil record of Picea dates from the late Eocene, with Cretaceous fossils questionable, with an origin now thought to be in boreal North America (Ledig et al., 2004; Ran et al., 2006). From this origin, it is hypothesized that Picea moved westward across the Bering Straits to Asia and south into Mexico, and from Asia to Europe. This migratory pathway across the Bering Strait existed throughout much of the Cretaceous and early Tertiary (Tiffney, 1985a,b).

Although more characteristic of cool temperate forest ecosystems in North America, three species of Picea are present today within the California MTC region. One of these is an unusual paleoendemic, Picea breweriana (weeping spruce, Figure 3), which is a phylogenetically isolated species with a basal position in the evolution of the genus (Ran et al., 2006). It is a local endemic restricted in distribution to montane forests in a small area of the Klamath Mountains where it occurs in mixed stands with as many as 15 different conifer species. This is a large tree that reaches up to $55 \mathrm{~m}$ in height and $1.5 \mathrm{~m}$ in diameter. Molecular studies suggest that it has had relatively stable small population sizes through the Quaternary (Chen et al., 2010).

Picea sitchensis (Sitka spruce) reaches it southern limit of distribution in the Coast Ranges of northern California from where it extends north into Alaska, forming pure or mixed conifer stands on cool and foggy coastal slopes. This is one of the largest tree species in the world, with individuals reaching $95 \mathrm{~m}$ in height and $6.5 \mathrm{~m}$ in diameter. Like P. breweriana, $P$. sitchensis has a basal position in the evolution of Picea (Ran et al., 2006). The third spruce species is Picea engelmannii (Engelmann spruce), a species present in the Cascade Ranges from northern California to Canada and eastward into the Rocky Mountains where it extends widely as a subalpine tree species. In the Pacific Northwest it reaches sizes up to heights of $60 \mathrm{~m}$ and diameters of $2.5 \mathrm{~m}$, although it often takes on a dwarfed growth form near treeline in the Rocky Mountains.

The genus Tsuga, hemlock, forms an important element of both lowland and subalpine forest communities in North America and Asia. Most studies today identify 8-10 extant species, although as many of 13 species have been suggested. Tsuga occurs in Japan, China, the Himalayas, western North America, and eastern North America. Molecular analyses suggest a diversification of an Eocene basal crown group with widespread circumpolar distribution followed by vicariance and extinction events leading to the present pattern of disjunct distribution (Havill et al., 2008). Two species of Tsuga are present in the 
California MTC region and form a distinct clade within the genus. Tsuga heterophylla (western hemlock) is distributed from northern California north to Alaska, as well as northern Rocky Mountains, in wet temperate forest habitats. As with the other species with this type of range described above, it is a large forest tree reaching to $80 \mathrm{~m}$ in height and diameters up to $3 \mathrm{~m}$. The second species is T. mertensiana (mountain hemlock) a species that extends in montane habitats from the southern Sierra Nevada through the Cascade Range and north to Alaska as well as in the northern Rocky Mountains. It is likewise a large tree reaching heights up to $50 \mathrm{~m}$ and diameters of $2 \mathrm{~m}$ or more. These two taxa overlap in distribution over much of their range but have distinct distribution patterns in California.

The genus Pseudotsuga includes 4-5 species, with a North America clade of three taxa with two of these occurring in the California MTC region. An Asian clade has one species each in Japan and China (this taxon sometimes divided into three species). Molecular studies and the fossil record together suggest that Pseudotsuga migrated from North America into eastern Asia via the Bering land bridge following the climatic cooling and rapid expansion of the Antarctic ice-sheets in the early Oligocene and then developed independently in warmer forest areas of Asia and North America during the late Oligocene to mid-Miocene warming period (Wei et al., 2010). Pseudotsuga is well-represented in the fossil record of western North America from the early Miocene (ca. 23 Ma) to the late Holocene. It has been debated whether the late Neogene or Quaternary glacial and interglacial shifts were responsible for the divergence of taxa in North America (Gugger et al., 2010).

The most widespread and economically significant species is Pseudotsuga menziesii (Douglas fir) with an extremely wide geographic range that extends from the Coast Ranges and central Sierra Nevada of California north to British Columbia and south in the Rocky Mountains to Central Mexico. The western range of the species east to the Cascade Range is a morphologically distinct from the Rocky Mountain variety, and the two have sometimes been considered to be separate species. Molecular studies have suggested that these two varieties diverged in the Pliocene about 2.1 Ma (Gugger et al., 2010). In contrast to its large congener, Pseudotsuga macrocarpa (big cone Douglas fir) is a highly restricted endemic in relatively dry upper foothill habitats of the Transverse Ranges of southern California. The time of divergence of the two California species has not been clearly established, but the two species have a range today that comes within $50 \mathrm{~km}$ of overlap in the southern Coast Ranges. A notable trait that differs in the southern California species is a larger seed adapted for animal dispersal in contrast to the small and more winged seeds of $P$. menziesii which are largely wind dispersed (Vander Wall et al., 2006).

\section{Pinaceae in the Mediterranean Basin}

The Mediterranean Basin is a rich geographic region for diversification of both pines and firs, including many regional endemics with limited ranges (Barbéro et al., 1998; Linares, 2011). All ten pine species present are members of the subgenus
Pinus. These can be divided into two groups with strong habitat correlations. One group is formed of five endemic species representing three different subsections of the yellow pines. These are the closely related the coastal P. halepensis (Aleppo pine, Figure 4) and P. brutia (Turkish or Calabrian pine) from the eastern Mediterranean, $P$. pinea (Italian stone pine) from southern Europe, Syria and Israel, $P$. pinaster (maritime pine) from the western Mediterranean Basin including North Africa, and montane $P$. canariensis (Canary Island pine) from the Canary Islands. Pinus roxburghii from mid-elevations Himalayas is also in this group, and, based on morphology, is likely the sister species to $P$. canariensis and represents another possible "Tethyan" distributional pattern.

The second group of Mediterranean pines are a mountain cluster in the subsection Pinus. This group includes $P$. sylvestris (Scots pine) which is widespread across Europe, plus five species that extend up to and just beyond the traditional boundary of mediterranean-climate regions. These are $P$. uncinata (Swiss mountain pine) from the Pyrenees and southern Alps, $P$. heldreichii (Bosnian pine) from the northeaster Mediterranean Basin, P. mugo (dwarf mountain pine) extending from the Alps to the Balkans, and P. nigra (black pine) with scattered subspecies across the Mediterranean Basin. A number of distinct populations of these species have received subspecific names.

The Mediterranean Basin presents an interesting example of late Neogene/Quaternary speciation in Abies, with nine species and one natural hybrid as well as several named varieties present. The present disjunct and highly localized distribution of many of these species has resulted from past climatic changes and associated migrations, population fragmentation, and hybridization (Scaltsoyiannes et al., 1999; Liepelt et al., 2010). While Abies fossils from the western Mediterranean indicate a wide Tertiary circum-Mediterranean distribution of the ancestor of the modern Abies taxa, palaeogeographical data suggest the possibility of a Tertiary ancestor from the eastern Mediterranean (Linares, 2011). Late Miocene, and Pliocene aridity together with marine transgressions hypothetically led to fragmentation and contraction of the range of a single ancestral Mediterranean fir species into a Balkan lineage (ancestor to A. alba) and an Asia Minor lineage (ancestor to A. bornmuelleriana).This separation lead to speciation following a southeastern to northwestern sequence of movement with A. cilicica (Turkey and Syria), A. numidica (Algeria), and A. pinsapo (Spain and Morocco), while frequent Pleistocene contacts between $A$. alba and $A$. bornmuelleriana could have led to the geographic isolation, local adaptations and genetic differentiation of $A$. nordmanniana (northern Turkey) and A. equi-trojani (western Turkey). Abies cephalonica (Greece, Figure 4) and A. nebrodensis (Sicily) may have originated through a past hybridization event or through genetic drift resulting from the prolonged isolation of southern populations of $A$. alba. Cyclical migrations of $A$. alba in the Pleistocene likely lead to contact with A. cephalonica in glacial refugia and the development of hybrid populations of $A$. borisiiregis in northern Greece (Linares, 2011).

Two of the generally accepted three species of cedars are endemic to the Mediterranean Basin. These are Cedrus atlantica 
from the Atlas Mountains of Morocco and Algeria, and C. libani from the Eastern Mediterranean Basin (Figure 4; DagherKharrat et al., 2007; Fady et al., 2008). Both are very large trees of montane habitats and often occur in relatively pure stands. Some authors separate populations of C. libani in the mountains of Cyprus as C. brevifolia. The origin of the genus is hypothesized to be from central Asia in the early Tertiary with a dispersal to the western Mediterranean by the Miocene. The Mediterranean Basin taxa appear to have diversified during drought cycles from ancestral populations of $C$. deodara from the western Himalayas (Qiao et al., 2007).

The primary center of diversity for Picea lies in temperate forest areas of eastern Asia. Just three species reach Europe or western Asia, with Picea abies just extending to the northern limits of the Mediterranean Basin in the southwestern Alps and northern Greece and Turkey.

\section{PODOCARPACEAE}

Considering their impressive ability to compete with angiosperms in the wet montane tropical forests, it is perhaps surprising the Podocarpaceae have enjoyed only limited success in temperate latitudes compared with the Pinaceae and Cupressaceae. Brodribb (2011) argued that the most significant limiting factor preventing greater ecological success of podocarps at the higher latitudes of the Southern Hemisphere today is drought. A major drying trend in the temperate regions of the Southern Hemisphere through the Neogene is associated with a period of significant podocarp contraction and extinction in Australia and other southern landmasses (Brodribb and Hill, 2004). Today, temperate latitude podocarps in the Southern Hemisphere are largely restricted to temperate rainforest or wet montane forest and are virtually absent from dry woodlands.

\section{Podocarpaceae in Chile}

The five members of the Podocarpaceae in southern Chile represent Gondwanan lineages and are restricted to mesic habitats (Armesto et al., 1995; Veblen et al., 2005). The most widespread of these is Podocarpus nubigenus which is distributed in Valdivian temperate rainforests of southern Chile and adjacent Argentina. Its range extends from south-central Chile to Última Esperanza Province at about $53^{\circ} \mathrm{S}$ lat, the latter extent making it the southernmost member of the Podocarpaceae in the world. Podocarpus nubigenus (mañio) s a medium to large tree that commonly reaches $20-25 \mathrm{~m}$ in height with occasional trees to $35 \mathrm{~m}$ (Figure 5). It is restricted to habitats with high levels of precipitation, generally with wet or swampy soils. Podocarpus salignus (mañio) is a second large Chilean podocarp, reaching $20 \mathrm{~m}$ in height and diameters of up to $1 \mathrm{~m}$. It favors Valdivian wet temperate rainforest and swampy habitats in a range from 35 to $42^{\circ} \mathrm{S}$ lat. in the Coastal Cordillera and Andes of southern Chile.

Saxegothaea conspicua (mañio) is a large tree characteristic of Valdivian temperate rainforests of southern Chile and adjacent Argentina, always in areas with high rainfall. Although slowgrowing, it reaches heights of $15-25 \mathrm{~m}$ and trunk diameters trunk up to $1 \mathrm{~m}$ or more. Despite its large stature, Saxegothaea commonly occurs as scattered individuals in a matrix of evergreen hardwood trees. Both P. nubigenus and Saxegothaea share a typical podocarp ecology. They are highly shade tolerant conifers that are most successful growing with dense canopy cover of associated hardwoods and low rates of stand disturbance. The great age reached by Saxegothaea, up to 750 years, and its ability to reproduce vegetatively aid in the success of this species (Lusk, 1996).

A fourth large podocarp tree characteristic of moderately wet forest habitats in southern Chile is Prumnopitys andina (lleuque). This species can grow to heights up to $30 \mathrm{~m}$ with diameters up to $2 \mathrm{~m}$. Most populations occur on the Andean slopes at elevations of $500-1,100 \mathrm{~m}$. There are 10 species in the genus Prumnopitys, representing a broad austral distribution of individual species in cool tropical montane or temperate forests. This range includes Costa Rica to the central Andes, New Zealand, northeastern Australia, and New Caledonia. Fossil representatives of Prumnopitys have been reported in early Miocene sediments in southern New Zealand with an age of about $20 \mathrm{Ma}$ (Pole, 2007).

Lepidothamnus fonkii, an unusual dwarf conifer growing in low mats generally no more than $10-50 \mathrm{~cm}$ in height, ranges in occurrence extends from about 40 to $55^{\circ} \mathrm{S}$ lat. in southern Chile and adjacent Argentina. The genus Lepidothamnus, also a Gondwanaland relict, includes three species, with the other two occurring in New Zealand. The characteristic habitat of $L$. fonkii in Chile is Sphagnum bogs or in mires dominated by cushion plants (Kleinebecker et al., 2007). Recent studies have shown active nitrogen fixation in root nodules of $L$. fonkii, a rare trait in Podocarpaceae, and it is hypothesized to play a prominent role in the nitrogen cycle of southern Patagonian bogs (Borken et al., 2016). Often it grows together with $P$. uviferum, and occasionally with F. cupressoides.

\section{Podocarpaceae in the Cape Region}

The genera Podocarpus and Afrocarpus are present in the Afro-montane forests of the Cape Region of South Africa, with all species considered to be temperate Afro-montane forest relicts (Midgley et al., 1995; Adie and Lawes, 2011). Podocarpus latifolius (yellowwood) is a common large tree reaching up to $30 \mathrm{~m}$ in height in Afro-montane forests along the south coast of the Cape Region, although also occurs as a shrubby tree on drier sites from the Cape Peninsula to the Eastern Cape and northern Transvaal. Its congener P. elongatus is a tall shrub or small tree, generally no more than about $6 \mathrm{~m}$ in height and often lower. In distribution it is confined to the winter-rainfall region of the Western Cape where it grows mainly on sandy soil, often along streams and rivers. Much less common is Afrocarpus falcatus (common yellowwood) which contributes tall forest trees in coastal and montane areas of Afro-montane forests from the Swellendam district in the Cape to the northern Transvaal and southern Mozambique. Large individuals can reach as much as $60 \mathrm{~m}$ in height and $2 \mathrm{~m}$ in diameter. Both A. falcatus and P. latifolius have been heavily harvested in the past for their wood. Fire and drought are major limiting factors for species today, and 
their range of distribution was altered by climate cycles of the Pleistocene.

\section{Podocarpaceae in Southwestern Australia}

Like many wet forest taxa, virtually all Podocarpaceae were lost from southwestern Australia with increasing aridity beginning in the Miocene. Today, there is only a single species in southwestern Australia, and indeed all of Western Australia. This is Podocarpus drouynianus, a understory shrub with a range restricted to wetter eucalypt forests (Figure 6). This species grows on sandy to gravelly loam soils, often in mesic stream habitats. It resprouts after fire, a persistence trait that no doubt was important in its survival (Brodribb and Hill, 2004).

\section{TAXACEAE}

\section{Taxaceae in California}

California is home to two paleoendemic taxa of Taxaceae. Taxus brevifolia (western yew), one of four species in the genus in North America, has a range that extends through mesic forests of Alaska and the Pacific Northwest to the central Sierra Nevada of California (Figure 3). It is sister to T. floridiana from Florida and T. globosa from Mexico, with a divergence time about 6-7 Ma (Li et al., 2001; Xiao et al., 2008). The clade of these three diverged species diverged from the other species of Taxus at about 916 Ma. Taxus brevifolia is a small to medium sized tree usually $5-10 \mathrm{~m}$ in height, but at its smaller size range in California. The genus includes 5-10 species depending on species concepts, with a wide range of occurrence around the Northern Hemisphere.

Torreya californica (California nutmeg) is a California paleoendemic with a highly restricted range of distribution in protected slopes and moist canyons of the Coast Ranges and Sierra Nevada. It is a small tree typically no more than $10 \mathrm{~m}$ in height but occasionally larger. It is one of the two North American members of this genus with the other the rare $T$. taxifolia restricted to a narrow belt along the Apalachicola River in Florida, the same location as the rare paleoendemic Taxus floridana. Torreya californica and T. taxifolia form a distinct clade within the genus that is separate from the other 3-5 Asian species in Japan and China. The genus is an ancient one with a fossil record that dates to the Jurassic of Europe and Cretaceous of the eastern United States. It is thought to have been a circumboreal group widely distributed at higher latitudes around the Northern Hemisphere before retreating in its range with climate changes in the Pliocene and Pleistocene (Li et al., 2001).

\section{Taxaceae in the Mediterranean Basin}

Taxus baccata represents a good example of a relict paleoendemic with a range today largely restricted to the western Mediterranean Basin. This species was much more widespread during most of the warm Middle-Late Pleistocene interglacials in France and Great Britain. It seems likely that most of the populations of $T$. baccata in the Mediterranean Basin have undergone repeated cycles of population isolation during periods of glaciations alternating with limited interglacial expansions during the Quaternary. These processes may have contributed significantly to enhance population divergence through restricted gene flow and genetic drift (González-Martínez et al., 2010).

\section{OVERVIEW}

All modern conifer families and several major subfamilial clades have roots that extend back to the Triassic and Jurassic when they were forest dominants. With the evolution and diversification of the angiosperms in the Cretaceous and continuing through the Eocene with a "hothouse" climate regime, the biogeographic and climatic distribution of conifers became much more restricted. The development of seasonal climates with aridity beginning in the Oligocene and increasing in the Miocene onwards, coupled with the presence of cool temperatures with extended frosts, allowed conifers to increase their success in competition with angiosperms and stimulated their diversification in the Northern Hemisphere. These climatic shifts through time, especially those associated with glaciation in the later Neogene and Pleistocene, favored the replacement of older lineages with those better adapted to cooler and/or drier conditions (Crisp and Cook, 2011; Leslie et al., 2012).

Measured on the basis of species richness, the Pinaceae and Podocarpaceae represent the two most diverse families of conifers with $230-250$ and 170-190 species, respectively, depending on species concepts. Together these two families comprise more than two-thirds of all conifer species. However, despite their successful evolutionary diversification since the Mesozoic, these two families differ significantly in traits of morphology, physiology, and ecology. The evolutionary and ecological success of each family has been built upon the differentiation of contrasting and rather canalized adaptive traits (Brodribb, 2011).

Species of Pinaceae thrive in in many ecosystems throughout the Northern Hemisphere, with only a single species reaching into the Southern Hemisphere in Malaysia. Members of this family are notably dominant in temperate forest environments where freezing limits the success of evergreen angiosperm competitors. Freezing has been described as the "great leveler" between conifers and angiosperms because it greatly narrows the hydraulic advantage of angiosperm wood (Feild et al., 2002). The narrow xylem tracheids that make up conifer wood are relatively resistant to freeze-thaw embolism, whereas the larger vessels of angiosperms are prone to embolism. In much of the area of temperate forests in the Northern Hemisphere where Pinaceae dominate, major freezing events are common during winter months and these conditions result in a freeze-induced shutdown of angiosperms for extended periods. These same traits of xylem anatomy that limit the formation of embolisms associated with freezing are also adaptive in working to prevent drought-induced 
embolism (Brodribb and Holbrook, 2005; Pittermann et al., 2012; Larter et al., 2015).

With its genetic diversity and ecophysiological tolerance of cold temperatures and drought the Pinaceae was well-positioned for success and diversification as global temperatures fell and seasonal aridity increased. Similarly, the Cupressoideae of the Cupressaceae was able to develop drought-tolerant lineages able to compete with angiosperms on azonal soils. Cyclical patterns climate dynamics and associated range contraction and expansion in response to glacial cycles led to isolated populations and speciation, especially in cool temperate montane and boreal environments where conifer ecophysiology allowed them to successfully compete with angiosperm trees (Waring and Franklin, 1979).

The California flora of exemplifies an environment that is both a "museum" for ancient conifer lineages and a nursery for Neogene/Quaternary conifer speciation (Ma et al., 2016). Of the 58 conifer species native to the region, 31 are endemic including notable examples of paleo-relicts as with S. sempervirens, S. giganteum, Abies bracteata, and $P$. breweriana (Table 1). However, the majority of the California endemics are examples of Neogene speciation in Hesperocyparis and Pinus. The other components of the extant conifer flora include 22 species with much of their range of distribution in wet temperate forest areas and five species extending broadly into more arid areas outside of the California MTC region. In a similar manner the conifer flora of the Mediterranean Basin has 32 of its 40 conifer species endemic, illustrated by examples of Neogene speciation in Juniperus, Abies, and Pinus. Seven species have their primary range in wetter and cooler climates. In these examples, the success of conifers in competition with angiosperms is generally associated with oligotrophic soils where the longevity and evergreen nature of conifer leaves makes them highly efficient in their nutrient-use (Waring and Franklin, 1979).

In contrast to the northern latitudes, the rich conifer diversity in the Southern Hemisphere at the end of the Eocene was distributed in relatively warm and mesic forest habitats moderated by oceanic climates because of the smaller hemispheric land area. Trees living in temperate forests never developed the extent of Neogene cold tolerance present in Northern Hemisphere temperate lineages (Markgraf et al., 1995). Many clades of Southern Hemisphere conifers became increasingly restricted to wet subtropical environments, favoring the survival of older lineages (Crisp and Cook, 2011; Leslie et al., 2012). The fossil record suggests that the Araucariaceae and mesic groups of Podocarpaceae and associated Nothofagus which had radiated across Australia in the Late Cretaceous and Early Cenozoic became reduced in diversity beginning in the Neogene. Extinctions over this period led to the loss of 10 genera of Podocarpaceae and two genera of Araucariaceae from Australia broadly and the almost complete loss of species from southwestern Australia. As a result, conifer lineages in the Southern Hemisphere today exhibit a significantly older distribution of divergence ages than their counterparts in the Northern
Hemisphere and present a number of isolated relict taxa (Crisp and Cook, 2011; Leslie et al., 2018).

Drought stress and appears to have been the significant factor for the Southern Hemisphere in the Neogene decrease in conifer diversity and dominance with competitive exclusion by radiating angiosperms and increased frequency of disturbance by fire (Brodribb and Hill, 1998; Crisp et al., 2019). As increasing seasonality and aridity led to cool and dry conditions in the late Miocene with a major reduction of rainforests and an increase in the extent of sclerophyll woodlands, fire became a prominent feature of disturbance regimes (Martin, 2006). Severe aridity set in during the Pliocene (5$2 \mathrm{Ma}$ ), resulting from steepening of the latitudinal temperature gradient across Australia, intensification of the subtropical high-pressure center, and expansion of the Antarctic ice cap (Bowler, 1982; Frakes, 1999; Byrne et al., 2008).

The three Southern Hemisphere MTC regions show dramatically lower levels of conifer diversity. This can be seen in Chile and the Cape Region where there has been little or no Neogene diversification and a preponderance of relict Gondwanan lineages. Only one of the nine of the Chilean conifers has a range that extends into the core MTC area of central Chile. The other species are Valdivian forest taxa that survive in wet temperate rainforest with a winter precipitation regime. There are no true MTC endemics. Unlike the high species richness and endemism of flowering plants, only three of the six conifers in the Cape Region are endemics. It is only in southwestern Australia that Callitris in has been able to evolve the appropriate drought-tolerant ecophysiological traits and adaptations to a fire-prone community to diversify (Larter et al., 2017; Crisp et al., 2019). Podocarpus drouynianus is a relict from a wetter era in the past.

The hydraulic traits associated with cold and/or drought tolerance that have served the Pinaceae well in the Northern Hemisphere have led to the economically successful introduction of many species in forest plantations in the Southern Hemisphere where they outperform native species (Higgins and Richardson, 1998; Richardson and Higgins, 1998). Pinus halepensis, P. radiata, and $P$. pinaster have been widely used in plantation forestry in fynbos shrublands of the Cape Region, while $P$. radiata is also widely grown in central and south-central Chile (Bustamante and Simonetti, 2005). Pseudotsuga menziesii, Pinus contorta, and $P$. ponderosa are now planted over extensive areas of Patagonian woodlands and grasslands (Langdon et al., 2010; Orellana and Raffaele, 2010). In many of these cases the nonnative conifers have become invasive, colonizing adjacent treeless habitats outside of plantation boundaries. This invasion of nonnative conifers into treeless native ecosystems opens the question of whether invasive non-native trees have increased fitness over native species in treeless areas or instead are exploiting an open niche (Rundel et al., 2014). Classic niche theory predicts that invaders with niches distinct from the native flora should coexist with little interaction with native species, yet successful invaders like many non-native conifers in the Southern Hemisphere have substantial impacts in shading out native species, competing for water, and/or facilitating changes in fire regime (Higgins 
and Richardson, 1998; Richardson and Higgins, 1998; Paritsis et al., 2018). Such invasions suggest that empty niches alone do not explain invasion success. MacDougall et al. (2009) have argued that while successful invader establishment can be based on either a fitness advantage or niche difference from native species, only the former allows invaders to become dominant. If this model is correct, it suggests that most examples of tree invasion into formerly treeless areas involve elements of both superior fitness and existing empty niches (Gyenge J. E. et al., 2008; Gyenge J. et al., 2008; Fernández et al., 2009).

\section{REFERENCES}

Adams, R. P. (2008). The Junipers of the World: The Genus Juniperus, 2nd Edn. Victoria, BC: Trafford Publishing.

Adams, R. P., Bartel, J. A., and Price, R. A. (2009). A new genus, Hesperocyparis, for the cypresses of the Western Hemisphere (Cupressaceae). Phytologia 91, 160-195.

Adie, H., and Lawes, M. J. (2011). "Podocarps in Africa: temperate zone relicts or rainforest survivors?," in Ecology of the Podocarpaceae in Tropical Forests, eds B. L. Turner and L. A. Cernusak, Smithsonian Contributions to Botany, No. 95. (Washington, DC: Smithsonian Institution Scholarly Press), 79-99. doi: 10.5479/si.0081024X.95.79

Allnutt, T. R., Newton, A. C., Lara, A., Premoli, A., Armesto, J. J., and Vergara, R., et al. (1999). Genetic variation in Fitzroya cupressoides (alerce), a threatened South American conifer. Mol. Ecol. 8, 975-987. doi: 10.1046/j.1365-294x.1999.00650.x

Allnutt, T. R., Newton, A. C., Premoli, A., and Lara, A. (2003). Genetic variation in the threatened South American conifer Pilgerodendron uviferum (Cupressaceae), detected using RAPD markers. Biol. Conserv. 114, 245-253. doi: 10.1016/S0006-3207(03)00044-2

Armesto, J. J., Villagrán, C., Aravena, J. C., Pérez, C., Smith-Ramirez, C., Cortés, M., et al. (1995). "Conifer forests of the Chilean coastal range," in Ecology of the Southern Conifers, eds N. J. Enright and R. S. Hill (Melbourne, VIC: Melbourne University Press), 56-170.

Axelrod, D. I. (1975). Evolution and biogeography of Madrean-Tethyan sclerophyll vegetation. Ann. Missouri Bot. Gard. 62, 280-334. doi: 10.2307/23 95199

Axelrod, D. I. (1976). Evolution of the Santa Lucia fir (Abies bracteata) ecosystem. Ann. Missouri Bot. Gard. 63, 24-41. doi: 10.2307/23 95221

Axelrod, D. I. (1980). History of the maritime closed-cone pines, Alta and Baja California. Univ. Calif. Publ. Geol. Sci. 120, 1-143.

Axelrod, D. I. (1986). Cenozoic history of some western pines. Ann. Missouri Bot. Gard. 73: 565-641 doi: 10.2307/2399194

Bagnoli, F., Vendramin, G. G., Buonamici, A., Doulis, A. G., González-Martínez, S. C., La Porta, N., et al. (2009). Is Cupressus sempervirens native in Italy? An answer from genetic and palaeobotanical data. Mol. Ecol. 18, 2276-2286. doi: 10.1111/j.1365-294X.2009.04182.x

Barbéro, M., Loisel, R., Quezel, P., Richardson, D. M., and Romane, F. (1998). "Pines of the Mediterranean Basin," in Ecology and Biogeography of Pinus, ed D. M. Richardson (Cambridge: Cambridge University Press), 153-170.

Bond, W. J. (1989). The tortoise and the hare: ecology of angiosperm dominance and gymnosperm persistence. Biol. J. Linn. Soc. 36, 227-249. doi: 10.1111/j.1095-8312.1989.tb00492.x

Borken, W., Horn, M. A., Geimer, S., Aguilar, N. A. B., and Knorr, K. H. (2016). Associative nitrogen fixation in nodules of the conifer Lepidothamnus fonkii (Podocarpaceae) inhabiting ombrotrophic bogs in southern Patagonia. Sci. Rep. 6:39072. doi: 10.1038/srep39072

Bowler, J. M. (1982). "Aridity in the late Tertiary and Quaternary of Australia," in Evolution of the Fauna of Arid Australia, eds W. R. Barker and P. J. M. Greenslade (Adelaide, SA:Peacock Publications), 35-46.

\section{AUTHOR CONTRIBUTIONS} The author confirms being the sole
contributor of this work and has approved it
for publication.

\section{FUNDING}

This research was funded by a grant no. 0120778 from the U.S. National Science Foundation to the Center for Embedded Networked Sensing.

Brodribb, N., and Holbrook, M. (2005). Water stress deforms tracheids peripheral to the leaf vein of a tropical conifer. Plant Physiol. 137, 1139-1146. doi: $10.1104 /$ pp. 104.058156

Brodribb, T., and Hill, R. S. (1998). The photosynthetic drought physiology of a diverse group of southern hemisphere conifer species is correlated with minimum seasonal rainfall. Funct. Ecol. 12, 465-471. doi: 10.1046/j.1365-2435.1998.00213.x

Brodribb, T., and Hill, R. S. (2004). "The rise and fall of the Podocarpaceae in Australia-a physiological explanation," in The Evolution of Plant Physiology, eds A. R. Hemsley and I. Poole (London: Elsevier Academic Press), 381-399. doi: 10.1016/B978-012339552-8/50020-2

Brodribb, T. J. (2011). "A functional analysis of podocarp ecology," in Ecology of the Podocarpaceae in Tropical Forests, eds B. L. Turner and L. A. Cernusak, Smithsonian Contributions to Botany, No. 95. (Washington, DC: Smithsonian Institution Scholarly Press), 165-173. doi: 10.5479/si.0081024X.95.165

Brown, R. W. (1935). Miocene leaves, fruits, and seeds from Idaho, Oregon, and Washington. J. Paleontol. 9, 572-587.

Burns, B. R. (1993). Fire-induced dynamics of Araucaria araucana-Nothofagus antarctica forest in the Southern Andes. J. Biogeogr. 20, 669-685. doi: $10.2307 / 2845522$

Bustamante, R. O., and Simonetti, J. A. (2005). Is Pinus radiata invading the native vegetation in central Chile? Demographic responses in a fragmented forest. Biol. Invasions 7, 243-249. doi: 10.1007/s10530-004-0740-5

Byrne, M., Yeates, D. K., Joseph, L., Kearney, M., Bowler, J., Williams, M. A. J., et al. (2008). Birth of a biome: insights into the assembly and maintenance of the Australian arid zone biota. Mol. Ecol. 17, 4398-4417. doi: 10.1111/j.1365-294X.2008.03899.x

Chen, C. H., Huang, J. P., Tsai, C. C., and Chaw, S. M. (2009). Phylogeny of Calocedrus (Cupressaceae), an eastern Asian and western North American disjunct gymnosperm genus, inferred from nuclear ribosomal nrITS. Bot. Stud. 50, 425-433

Chen, J., Källman, T., Gyllenstrand, N., and Lascoux, M. (2010). New insights on the speciation history and nucleotide diversity of three boreal spruce species and a Tertiary relict. Heredity 104, 3-14. doi: 10.1038/hdy.2009.88

Cowling, R. M., Potts, A. J., Bradshaw, P., Colville, J., Arianoutsou, M., Ferrier, S., et al. (2015). Variation in plant diversity in mediterranean climate ecosystems: the role of climatic and topographical stability. J. Biogeogr. 43, 552-564. doi: $10.1111 /$ jbi.12429

Cowling, R. M., Rundel, P. W., Lamont, B. B., Arroyo, M. K., and Arianoutsou, M. (1996). Plant diversity in Mediterranean-climate regions. Trends Ecol. Evol. 11, 352-360. doi: 10.1016/0169-5347(96)10044-6

Crisp, M. D., and Cook, L. G. (2011). Cenozoic extinctions account for the low diversity of extant gymnosperms compared with angiosperms. New Phytol. 192, 997-1009. doi: 10.1111/j.1469-8137.2011.03862.x

Crisp, M. D., and Cook, L. G. (2013). How was the Australian flora assembled over the last 65 million years? A molecular phylogenetic perspective. Ann. Rev. Ecol. Evol. Syst. 44, 303-324. doi: 10.1146/annurev-ecolsys-110512-135910

Crisp, M. D., Cook, L. G., Bowman, D. M., Cosgrove, M., Isagi, Y., and Sakaguchi, S. (2019). Turnover of southern cypresses in the post-Gondwanan world: extinction, transoceanic dispersal, adaptation and rediversification. New Phytol. 221, 308-2319. doi: 10.1111/nph.15561 
Dagher-Kharrat, M. B., Mariette, S., Lefevre, F., Fady, B., Grenier-de March, G., Plomion, C., et al. (2007). Geographical diversity and genetic relationships among Cedrus species estimated by AFLP. Tree Genet. Genomes 3, 275-285. doi: 10.1007/s11295-006-0065-x

Donoghue, M. J., and Smith, S. A. (2004). Patterns in the assembly of temperate forests around the Northern Hemisphere. Philos. Trans. R. Soc. Lond. Ser. B Biol. Sci. 359, 1633-1644. doi: 10.1098/rstb.2004.1538

Eckert, A. J. (2008). A phylogeographical analysis of the range disjunction for foxtail pine (Pinus balfouriana, Pinaceae): the role of Pleistocene glaciation. Mol. Ecol. 17, 1983-1997. doi: 10.1111/j.1365-294X.2008.03722.x

Eckert, A. J., and Hall, B. D. (2006). Phylogeny, historical biogeography, and patterns of diversification for Pinus (Pinaceae): phylogenetic tests of fossil-based hypotheses. Mol. Phylogenet. Evol. 40, 166-182. doi: 10.1016/j.ympev.2006.03.009

Escapa, I. H., Iglesias, A., Wilf, P., Catalano, S. A., Caraballo-Ortiz, M. A., and Rubén Cúneo, N. (2018). Agathis trees of Patagonia's CretaceousPaleogene death landscapes and their evolutionary significance. Am. J. Bot. 105, 1345-1368. doi: 10.1002/ajb2.1127

Fady, B., Lefèvre, F., Vendramin, G. G., Ambert, A., Régnier, C., and Bariteau, M. (2008).Genetic consequences of past climate and human impact on eastern Mediterranean Cedrus libani forests. Implications for their conservation. Conserv. Genet. 9, 85-95. doi: 10.1007/s10592-0079310-6

Feild, T. S., Brodribb, T., and Holbrook, N. M. (2002). Hardly a relict: freezing and the evolution of vesselless wood in Winteraceae. Evolution 56, 464-478. doi: 10.1111/j.0014-3820.2002.tb01359.x

Fernández, M. E., Gyenge, J., and Schlichter, T. (2009). Water flux and canopy conductance of natural versus planted forests in Patagonia, South America. Trees 23, 415-427. doi: 10.1007/s00468-008-0291-y

Fites-Kaufman, J. A., Rundel, P. W., Stephenson, N., and Weixelman, D. A. (2007). "Montane and subalpine vegetation of the Sierra Nevada and Cascade Ranges," in Terrestrial Vegetation of California, eds M. Barbour, A. Schoenherr, and T. Keeler-Wolf (Berkeley, CA: University of California Press), 456-501. doi: 10.1525/california/9780520249554.003.0017

Frakes, L. A. (1999). "Evolution of Australian environments," in Flora of Australia, Vol. 1. Introduction, ed A. E. Orchard (Melbourne, VIC: CSIRO Publishing), 163-203.

Gadek, P. A., Alpers, D. L., Heslewood, M. M., and Quinn, C. J. (2000). Relationships within Cupressaceae sensu lato: a combined morphological and molecular approach. Am. J. Bot. 87, 1044-1057. doi: 10.2307/26 57004

Gernandt, D. S., Liston, A., and Piñero, D. (2003). Phylogenetics of Pinus subsections Cembroides and Nelsoniae inferred from cpDNA sequences. Syst. Bot. 28, 657-673. doi: 10.1043/02-63.1

González-Martínez, S. C., Dubreuil, M., Riba, M., Vendramin, G. G., Sebastiani, F., and Mayol, M. (2010). Spatial genetic structure of Taxus baccata L. in the western Mediterranean Basin: past and present limits to gene movement over a broad geographic scale. Mol. Phylogenet. Evol. 55, 805-815. doi: 10.1016/j.ympev.2010.03.001

Greguss, P. A. (1970). Callitris-like wood from the Tertiary of Limburg, Netherlands Senckenbergiana. Lethaea 51, 265-275.

Gugger, P. F., Sugita, S., and Cavender-Bares, J. (2010). Phylogeography of Douglas-fir based on mitochondrial and chloroplast DNA sequences: testing hypotheses from the fossil record. Mol. Ecol. 19, 1877-1897. doi: 10.1111/j.1365-294X.2010.04622.x

Gyenge, Fernández, M. E., Sarasola, M., and Schlichter, T. (2008). Testing a hypothesis of the relationship between productivity and water use efficiency in Patagonian forests with native and exotic species. For. Ecol. Manage. 255, 3281-3287. doi: 10.1016/j.foreco.2008.01.078

Gyenge, J. E., Fernández, M. E., and Schlichter, T. M. (2008). Are differences in productivity between native and exotic trees in NW Patagonia related to differences in hydraulic conductance? Trees 22, 483-490. doi: 10.1007/s00468-008-0208-9

Havill, N. P., Campbell, C. S., Vining, T. F., LePage, B., Bayer, R. J., and Donoghue, M. J. (2008). Phylogeny and biogeography of Tsuga (Pinaceae) inferred from nuclearribosomal ITS and chloroplast DNA sequence data. Syst. Bot. 33, 478-489. doi: 10.1600/036364408785 679770
He, T., Pausas, J. G., Belcher, C. M., Schwilk, D. W., and Lamont, B. B. (2012). Fireadapted traits of Pinus arose in the fiery Cretaceous. New Phytol. 194, 751-759. doi: 10.1111/j.1469-8137.2012.04079.x

Higgins, S. I., and Richardson, D. M. (1998). Pine invasions in the southern hemisphere: modelling interactions between organism, environment and disturbance. Plant Ecol. 135, 79-93. doi: 10.1023/A:10097605 12895

Hill, R. S. (1990). Araucaria (Araucariaceae) species from Australian Tertiary sediments: a micromorphological study. Aust. Syst. Bot. 3, 203-220. doi: $10.1071 /$ SB9900203

Hill, R. S. (1995). "Conifer origin, evolution and diversification in the southern hemisphere," in Ecology of the Southern Conifers, eds N. J. Enright and R. S. Hill (Melbourne, VIC: Melbourne University Press), 10-29.

Hill, R. S. (2004). Origins of the southeastern Australian vegetation. Philos. Trans. R. Soc. Lond. Ser. B 359, 1537-1549. doi: 10.1098/rstb.2004.1526

Hill, R. S., and Brodribb, T. J. (2006). “The evolution of Australia’s living biota," in Ecology: An Australian Perspective, eds P. Attiwill and B. Wilson (Melbourne, VIC: Oxford University Press), 19-40.

Hill, R. S., and Whang, S. S. (1996). A new species of Fitzroya (Cupressaceae) from Oligocene sediments in north-western Tasmania. Aust. Syst. Bot. 9, 867-875. doi: 10.1071/SB9960867

Jalut, G., Marti, J. M., Fontugne, M., Delibrias, G., Vilaplana, J. M., and Julia, R. (1992). Glacial to interglacial vegetation changes in the northern and southern Pyrenees: deglaciation, vegetation cover and chronology. Quat. Sci. Rev. 11, 449-480. doi: 10.1016/0277-3791(92)90027-6

Keeley, J. E., and Zedler, P. H. (1998). "Evolution of life histories in Pinus," in Ecology and biogeography of Pinus, ed Richardson (Cambridge: Cambridge University Press), 219-251.

Kleinebecker, T., Hölzel, N., and Voge, A. (2007). Gradients of continentality and moisture in South Patagonian ombrotrophic peatland. Folia Geobot. 42, 363-382. doi: 10.1007/BF02861700

Kvaček, Z., Manchester, S. R., and Schorn, H. E. (2000). Cones, seeds, and foliage of Tetraclinis salicornioides (Cupressaceae) from the Oligocene and Miocene of western North America: a geographic extension of the European Tertiary species. Int. J. Plant Sci. 161, 331-344. doi: 10.1086/314245

Lamont, B. B., and Downes, K. S. (2011). Fire-stimulated flowering among resprouters and geophytes in Australia and South Africa. Plant Ecol. 212, 2111-2125. doi: 10.1007/s11258-011-9987-y

Langdon, B., Pauchard, A., and Aguayo, M. (2010). Pinus contorta invasion in the Chilean Patagonia: local patterns in a global context. Biol. Invas. 12, 3961-3971. doi: 10.1007/s10530-010-9817-5

Lara, A. Y., and Villalba, R. (1993). A 3620-year temperature record from Fitzroya cupressoides tree rings in Southern America. Science 260, 1104-1106. doi: 10.1126/science.260.5111.1104

Larter, M., Brodribb, T. J., Pfautsch, S., Burlett, R., Cochard, H., and Delzon, S. (2015). Extreme aridity pushes trees to their physical limits. Plant Physiol. 168, 804-807. doi: 10.1104/pp.15.00223

Larter, M., Pfautsch, S., Domec, J. C., Trueba, S., Nagalingum, N., and Delzon, S. (2017). Aridity drove the evolution of extreme embolism resistance and the radiation of conifer genus Callitris. New Phytol. 215, 97-112. doi: 10.1111/nph.14545

Ledig, F. T., Hodgskiss, P. D., and Johnson, D. R. (2006). Genetic diversity and seed production in Santa Lucia fir (Abies bracteata), a relict of the Miocene broadleaved evergreen forest. Conserv. Genet. 7, 383-398. doi: 10.1007/s10592-005-9049-x

Ledig, F. T., Hodgskiss, P. D., Krutovskii, K. V., Neale, D. B., and Eguiluz-Piedra, T. (2004). Relationships among the spruces (Picea, Pinaceae) of southwestern North America. Syst. Bot. 29, 275-295. doi: 10.1600/036364404774195485

Leslie, A. B., Beaulieu, J., Holman, G., Campbell, C. S., Mei, W., Raubeson, L. R., et al. (2018). An overview of extant conifer evolution from the perspective of the fossil record. Am. J. Bot. 105, 1531-1544. doi: 10.1002/ajb2.1143

Leslie, A. B., Beaulieu, J. M., Rai, H. S., Crane, P. R., Donoghue, M. J., and Mathews, S. (2012). Hemisphere-scale differences in conifer evolutionary dynamics. Proc. Natl. Acad. Sci. U.S.A. 109, 16217-16221. doi: 10.1073/pnas.1213621109

Li, J., Davis, C. C., Del Tredici, P., and Donoghue, M. J. (2001). Phylogeny and biogeography of Taxus (Taxaceae) inferred from sequences of the internal transcribed spacer region of nuclear ribosomal DNA. Harv. Pap. Bot. 6, 267-274. 
Li, J. H., and Xiang, Q. P. (2005). Phylogeny and biogeography of Thuja, L. (Cupressaceae), an eastern Asian and North American disjunct genus. J. Integr. Plant Biol. 47, 651-659. doi: 10.1111/j.1744-7909.2005.00087.x

Liepelt, S., Mayland-Quellhorst, E., Lahme, M., and Ziegenhagen, B. (2010). Contrasting geographical patterns of ancient and modern genetic lineages in Mediterranean Abies species. Plant Syst. Evol. 284, 141-151. doi: 10.1007/s00606-009-0247-8

Linares, J. C. (2011). Biogeography and evolution of Abies (Pinaceae) in the Mediterranean Basin: the roles of long-term climatic change and glacial refugia. J. Biogeogr. 38, 619-630. doi: 10.1111/j.1365-2699.2010.02458.x

Lusk, C. H. (1996). Stand dynamics of the shade-tolerant conifers Podocarpus nubigena and Saxegothaea conspicua in Chilean temperate rain forest. J. Veget. Sci. 7, 549-558. doi: 10.2307/3236304

Ma, Z., Sandel, B., and Svenning, J. C. (2016). Phylogenetic assemblage structure of North American trees is more strongly shaped by glacial-interglacial climate variability in gymnosperms than in angiosperms. Ecol. Evol. 6, 3092-3106. doi: $10.1002 /$ ece 3.2100

MacDougall, A. S., Gilbert, B., and Levine, J. M. (2009). Plant invasions and the niche. J. Ecol. 97, 609-615. doi: 10.1111/j.1365-2745.2009. 01514.x

Malusa, J. (1992). Phylogeny and biogeography of the pinyon pines. (Pinus subsect. Cembroides). Syst. Bot. 17, 42-66. doi: 10.2307/2419064

Manders, P. T. (1987). A transition matrix model of the population dynamics of the Clanwilliam Cedar (Widdringtonia cedarbergensis) in natural stands subject to fire. For. Ecol. Manage. 20, 171-186. doi: 10.1016/0378-1127(87)90157-5

Mao, K., Hao, G., Liu, J., Adams, R. P., and Milne, R., I. (2010). Diversification and biogeography of Juniperus (Cupressaceae): variable diversification rates and multiple intercontinental dispersals. New Phytol. 188, 254-272. doi: 10.1111/j.1469-8137.2010.03351.x

Mao, K., Milne, R. I., Zhang, L., Peng, Y., Liu, J., Thomas, P., et al. (2012). Distribution of living Cupressaceae reflects the breakup of Pangea. Proc. Natl. Acad. Sci. U.S.A. 109, 7793-7798. doi: 10.1073/pnas.1114319109

Marchelli, P., Baier, C., Mengel, C., Ziegenhagen, B., and Gallo, L. A. (2010). Biogeographic history of the threatened species Araucaria araucana (Molina) K. Koch and implications for conservation: a case study with organelle DNA markers. Conserv. Genet. 11, 951-963. doi: 10.1007/s10592-0099938-5

Markgraf, V., McGlone, M., and Hope, G. (1995). Neogene paleoenvironmental and paleoclimatic change in southern temperate ecosystems - a southern perspective. Trends Ecol. Evol. 10, 143-147. doi: 10.1016/S0169-5347(00)89023-0

Martin, H. A. (2006). Cenozoic climatic changes and the development of the arid vegetation of Australia. J. Arid Environ. 66, 533-563. doi: 10.1016/j.jaridenv.2006.01.009

McIver, E. E. (2001). Cretaceous Widdringtonia Endl. (Cupressaceae) from North America. Int. J. Plant Sci. 162, 937-961. doi: 10.1086/320776

Médail, F., Quézel, P., Besnard, G., and Khadari, B. (2009). Systematics, ecology and phylogeographic significance of Olea europaea L. ssp. maroccana (Greuter \& Burdet) P. Vargas et al., a relictual olive tree in south-west Morocco. Bot. J. Linn. Soc. 137, 249-266. doi: 10.1111/j.1095-8339.2001.tb01121.x

Midgley, J. J., Bond, W. J., and Geldenhuys, C. J. (1995). "The ecology of southern African conifers," in Ecology of the Southern Conifers, eds N. J. Enright and R. S. Hill (Melbourne, VIC: Melbourne University Press), 64-80.

Millar, C. (1993). Impact of the Eocene on the evolution of Pinus, L. Ann. Missouri Botan. Gard. 80, 471-498. doi: 10.2307/2399795

Millar, C. (1999). Evolution and biogeography of Pinus radiata, with a proposed revision of its Quaternary history. N. Z. J. For. Sci. 29, 335-365.

Millar, C. I., Strauss, S. H., Conkle, T. H., and Westfall, R. D. (1988). Allozyme differentiation and biosystematics of the California closed-cone pines (Pinus subsection Oocarpae). Syst. Bot. 13, 351-370. doi: 10.2307/2419298

Orellana, I. A., and Raffaele, E. (2010). The spread of the exotic conifer Pseudotsuga menziesii in Austrocedrus chilensis forests and shrublands in northwestern Patagonia, Argentina. N. Z. J. For. Sci. 40, 199-209.

Panti, C., Cesari, S. N., Marenssi, S. A., and Olivero, E. B. (2007). A new araucarian fossil species from the Paleogene of southern Argentina. Ameghiniana $44,215-222$.

Paritsis, J., Landesmann, J. B., Kitzberger, T., Tiribelli, F., Sasal, Y., Quintero, C., et al. (2018). Pine plantations and invasion alter fuel structure and potential fire behavior in a Patagonian forest-steppe Ecotone. Forests 9:117. doi: 10.3390/f9030117

Pastorino, M. J., and Gallo, L. A. (2002). Quaternary evolutionary history of Austrocedrus chilensis, a cypress native to the Andean-Patagonian forest. J. Biogeogr. 29, 1167-1178. doi: 10.1046/j.1365-2699.2002. 00731.x

Pastorino, M. J., Gallo, L. A., and Hattemer, H. H. (2004). Genetic variation in natural populations of Austrocedrus chilensis, a cypress of the Andean-Patagonian forest. Biochem. Syst. Ecol. 32, 993-1008. doi: $10.1016 /$ j.bse.2004.03.002

Paull, R., and Hill, R. S. (2008). Oligocene Austrocedrus from Tasmania (Australia): comparisons with Austrocedrus chilensis. Int. J. Plant Sci. 169, 315-330. doi: $10.1086 / 523963$

Paull, R., and Hill, R. S. (2010). Early Oligocene Callitris and Fitzroya (Cupressaceae) from Tasmania. Am. J. Bot. 97, 809-820. doi: $10.3732 / a j b .0900374$

Pauw, C. A., and Linder, H. P. (1997). Tropical African cedars (Widdringtonia, Cupressaceae): systematics, ecology and conservation status. Bot. J. Linn. Soc. 123, 297-319. doi: 10.1111/j.1095-8339.1997.tb01421.x

Piggin, J. A., and Bruhl, J. J. (2010). Phylogeny reconstruction of Callitris Vent. (Cupressaceae) and its allies leads to inclusion of Actinostrobus within Callitris. Austr. Syst. Bot. 23, 69-93. doi: 10.1071/SB09044

Pittermann, J., Stuart, S. A., Dawson, T. E., and Moreau, A. (2012). Cenozoic climate change shaped the evolutionary ecophysiology of the Cupressaceae conifers. Proc. Natl. Acad. Sci. U.S.A. 109, 9647-9652. doi: 10.1073/pnas.1114378109

Pledge, N. S. (2002). First Report of Cupressacean Cones in the Eocene Eyre Formation of South Australia. Records of the South Australian Museum (Adelaide), 185-191.

Pole, M. (2007). Conifer and cycad distribution in the Miocene of southern New Zealand. Aust. J. Bot. 55, 143-164. doi: 10.1071/BT06056

Premoli, A. C., Kitzberger, T., and Veblen, T. T. (2000). Isozyme variation and recent biogeographical history of the long-lived conifer Fitzroya cupressoides. J. Biogeogr. 27, 251-260. doi: 10.1046/j.1365-2699.2000.00402.x

Premoli, A. C., Souto, C. P., Rovere, A. E., Allnut, T. R., and Newton, A. C. (2002). Patterns of isozyme variation as indicators of biogeographic history in Pilgerodendron uviferum. Divers. Distrib. 8, 57-66. doi: 10.1046/j.1472-4642.2002.00128.x

Premoli, A. C., Vergara, R., Souto, C. P., Souto, C. P., Lara, A., and Newton, A. C. (2003). Lowland valleys shelter the ancient conifer Fitzroya cupressoides in the Central Depression of southern Chile. J. R. Soc. N. Z. 33, 623-631. doi: $10.1080 / 03014223.2003 .9517749$

Pye, M. G., Gadek, P. A., and Edwards, K. J. (1998). Divergence, diversity and species of the Australasian Callitris (Cupressaceae) and allied genera: evidence from ITS sequence data. Aust. Syst. Bot. 16, 505-514. doi: 10.1071/SB02019

Qiao, C. Y., Ran, J. H., Li, Y., and Wang, X. Q. (2007). Phylogeny and biogeography of Cedrus (Pinaceae) inferred from sequences of seven paternal chloroplast and maternal mitochondrial DNA regions. Ann. Bot. 100, 573-580. doi: $10.1093 / \mathrm{aob} / \mathrm{mcm} 134$

Quézel, P., Médail, F., Loisel, R., and Barbero, M. (1999). Biodiversity and conservation of forest species in the Mediterranean basin. UNASYLVA-FAO 50, $21-28$.

Rabassa, J., and Clapperton, C. M. (1990). Quaternary glaciations of the Southern Andes. Quat. Sci. Rev. 9, 153-174. doi: 10.1016/0277-3791(90)90016-4

Ran, J. H., Wei, X. X., and Wang, X. Q. (2006). Molecular phylogeny and biogeography of Picea (Pinaceae): implications for phylogeographical studies using cytoplasmic haplotypes. Mol. Phylogenet. Evol. 41, 405-419. doi: 10.1016/j.ympev.2006.05.039

Rehfeldt, G. E. (1997). Quantitative analysis of the genetic structure of closely related conifers with disparate distributions and demographics: the Cupressus arizonica (Cupressaceae) complex. Amer. J. Bot. 84, 190-200. doi: $10.2307 / 2446080$

Richardson, D. M., and Higgins, S. L. (1998). "Pines as invaders in the Southern hemisphere," in Ecology and Biogeography of Pinus, ed D. M. Richardson (Cambridge: Cambridge University Press), 450-473.

Richardson, D. R., and Rundel, P. W. (1998). "Introduction: biogeography and ecology of pines," in Biogeography and Ecology of Pinus, ed D. R. Richardson (Cambridge: Cambridge University Press), 3-46. 
Ruiz, E., González, F., Torres-Díaz, C., Fuentes, G., Mardones, M., Stuessy, T., et al. (2007). Genetic diversity and differentiation within and among Chilean populations of Araucaria araucana (Araucariaceae) based on allozyme variability. Taxon 56, 1221-1228. doi: 10.2307/25065913

Rundel, P. W. (1972). Habitat restriction in giant sequoia: environmental control of grove boundaries. Am. Midland Natur. 87, 81-99. doi: 10.2307/2423883

Rundel, P. W. (2011). "Convergence and divergence in mediterranean-climate ecosystems: what we can learn by comparing similar places,"in The Ecology of Place, eds M. Price and I. Billick (Chicago, IL: University of Chicago Press), 93-108.

Rundel, P. W., Arroyo, M., Cowling, T. K., Keeley, R. M., Lamont, J. E., Pausas, B. B., et al. (2018). Fire and plant diversification in mediterranean-climate regions. Front. Plant Sci. 9:851. doi: 10.3389/fpls.2018.00851

Rundel, P. W., Arroyo, M. K., Cowling, R. M., Keeley, J. E., Lamont, B. B., and Vargas, P. (2016). Mediterranean biomes: evolution of the floras, vegetation, and climate regime. Annu. Rev. Ecol. Evol. Syst. 47, 383-407. doi: 10.1146/annurev-ecolsys-121415-032330

Rundel, P. W., Dickie, I. A., and Richardson, D. M. (2014). Tree invasions into treeless areas: mechanisms and ecosystem processes. Biol. Invasions 16, 663-675. doi: 10.1007/s10530-013-0614-9

Sawyer, J. O., Gray, J., West, G. J., Thornburgh, D. A., Noss, R. F., and Engbeck, J. H. (2000). "History of redwood and redwood forests," in The Redwood Forest. History, Ecology and Conservation of Redwoods, ed R. F. Noss (Washington: Save-the-Redwoods League), 7-38.

Scaltsoyiannes, A., Tsaktsira, M., and Drouzas, A. D. (1999). Allozyme differentiation in the Mediterranean firs (Abies, Pinaceae). A first comparative study with phylogenetic implications. Plant Syst. Evol. 216, 289-307. doi: 10.1007/BF01084404

Schwilk, D. W., and Ackerly, D. D. (2001). Flammability and serotiny as strategies: correlated evolution in pines. Oikos 94, 326-336. doi: 10.1034/j.1600-0706.2001.940213.x

Sekiewicz, K., Dering, M., Romo, A., Dagher-Kharrat, M. B., Boratynska, K., Ok, T., et al. (2018). Phylogenetic and biogeographic insights into long-lived Mediterranean Cupressus taxa with a schizo-endemic distribution and Tertiary origin. Bot. J. Linn. Soc. 188, 190-212. doi: 10.1093/botlinnean/boy049

Terrab, A., Schönswetter, P., Talavera, S., Vela, E., and Stuessy, T. F. (2008). Rangewide phylogeography of Juniperus thurifera L., a presumptive keystone species of western Mediterranean vegetation during cold stages of the Pleistocene. Mol. Phyl. Evol. 48, 94-102. doi: 10.1016/j.ympev.2008.03.018

Terry, R. G., Pyne, M. I., Bartel, J. A., and Adams, R. P. (2016). A molecular biogeography of the New World cypresses (Callitropsis, Hesperocyparis; Cupressaceae). Plant Syst. Evol. 302, 921-942. doi: 10.1007/s00606-016-1308-4

Teste, F. P., Kardol, P., Turner, B. L., Wardle, D. A., Zemunik, G., Renton, M., et al. (2017). Plant-soil feedback and the maintenance of diversity in Mediterraneanclimate shrublands. Science 355, 173-176. doi: 10.1126/science.aai8291

Tiffney, B. H. (1985a). Perspectives on the origin of the floristic similarity between Eastern Asia and eastern North America. J. Arnold Arbor. 66, 73-94. doi: 10.5962/bhl.part.13179

Tiffney, B. H. (1985b). The Eocene North Atlantic land bridge: its importance in Tertiary and modern phytogeography of the Northern Hemisphere. J. Arnold Arbor. 66, 243-273. doi: 10.5962/bhl.part.13183

Vander Wall, S. B., Borchert, M. I., and Gworek, J. R. (2006). Secondary dispersal of bigcone Douglas-fir (Pseudotsuga macrocarpa) seeds. Acta Oecol. 30, 100-106. doi: 10.1016/j.actao.2006.02.004
Veblen, T. T., Armesto, J. J., Burns, B. R., Kitzberger, T., Lara, A., León, B., et al. (2005). "The coniferous forests of South America," in Ecosystems of the World: Coniferous Forests, ed F. A. Andersonn (Amsterdam: Elsevier), 701-725.

Veblen, T. T., Burns, B. R., Kitzberger, T., Lara, A., and Villalba, R. (1995). “The ecology of the conifers of southern South America," in Ecology of the Southern Conifers, eds N. J. Enright and R. S. Hill (Carlton, VIC: Melbourne University Press), 120-155.

Villagrán, C. (1995). “Quaternary history of the mediterranean vegetation of Chile," in Ecology and Biogeography of Mediterranean Ecosystems in Chile, California and Australia, eds M. T. K. Arroyo, P. H. Zedler, and M. D. Fox (Berlin: Springer Verlag), 3-20. doi: 10.1007/978-1-4612-2490-7_1

Waring, R. H., and Franklin, J. F. (1979). Evergreen forests of the Pacific Northwest. Science 204, 1380-1385. doi: 10.1126/science.204.4400.1380

Wei, X. X., Yang, Z. Y., Li, Y., and Wang, X. Q. (2010). Molecular phylogeny and biogeography of Pseudotsuga (Pinaceae): insights into the floristic relationship between Taiwan and its adjacent areas. Mol. Phylogenet. Evol. 55, 776-785. doi: 10.1016/j.ympev.2010.03.007

Wilf, P., Escapa, I. H., Cúneo, N. R., Kooyman, R. M., Johnson, K. R., and Iglesias, A. (2014). First South American Agathis (Araucariaceae), Eocene of Patagonia. Am. J. Bot. 101, 156-179. doi: 10.3732/ajb.13 00327

Willyard, A., Syring, J., Gernandt, D. S., Liston, A., and Cronn, R. (2006). Fossil calibration of molecular divergence infers a moderate mutation rate and recent radiations for Pinus. Mol. Biol. Evol. 24, 90-101. doi: 10.1093/molbev/msl207

Wolf, C. B. (1948). Taxonomic and distributional studies of the New World cypresses. El Aliso 1, 1-250. doi: 10.5642/aliso.19480 101.02

Wu, J. K., Krutovskii, V., and Strauss, S. H. (1999). Nuclear DNA diversity, population differentiation, and phylogenetic relationships in the California closed-cone pines based on RAPD and allozyme markers. Genome 42, 893-908. doi: 10.1139/gen-42-5-893

Xiang, Q.-P., Xiang, Q.-Y., Liston, A., and Zhang, X.-C. (2004). Phylogenetic relationships in Abies (Pinaceae): evidence from PCR-RFLP of the nuclear ribosomal DNA internal transcribed spacer region. Bot. J. Linn. Soc. 145, 425-435. doi: 10.1111/j.1095-8339.2004.00286.x

Xiang, Q. P., Xiang, Q. Y., Guo, Y. Y., and Zhang, X. C. (2009). Phylogeny of Abies (Pinaceae) inferred from nrITS sequence data. Taxon 58, 141-152. doi: $10.1002 / \operatorname{tax} .581015$

Xiao, P. G., Huang, B., Ge, G. B., and Yang, L. (2008). Interspecific relationships and origins of Taxaceae and Cephalotaxaceae revealed by partitioned Bayesian analyses of chloroplast and nuclear DNA sequences. Plant Syst. Evol. 276, 89-104. doi: 10.1007/s00606-008-0069-0

Conflict of Interest: The author declares that the research was conducted in the absence of any commercial or financial relationships that could be construed as a potential conflict of interest.

Copyright (C) 2019 Rundel. This is an open-access article distributed under the terms of the Creative Commons Attribution License (CC BY). The use, distribution or reproduction in other forums is permitted, provided the original author(s) and the copyright owner(s) are credited and that the original publication in this journal is cited, in accordance with accepted academic practice. No use, distribution or reproduction is permitted which does not comply with these terms. 